\title{
"PLAYING IT SAFE" WITH EMPIRICAL EVIDENCE: SELECTIVE USE OF SOCIAL SCIENCE IN SUPREME COURT CASES ABOUT RACIAL JUSTICE AND MARRIAGE EQUALITY
}

\author{
Russell K. Robinson and David M. Frost
}

\begin{abstract}
This Essay seeks to draw connections between race, sexual orientation, and social science in Supreme Court litigation. In some respects, advocates for racial minorities and sexual minorities face divergent trajectories. Among those asserting civil rights claims, LGBT rights claimants have been uniquely successful at the Court ever since Romer v. Evans in the mid-1990s. During this period, advocates for racial minorities have fought to preserve earlier victories in cases such as Regents of the University of California v. Bakke and have failed to overturn precedents that strictly limit equal protection possibilities, such as McCleskey v. Kemp. Nonetheless, we argue that the Court's "fear of too much justice" links race and sexual orientation cases and helps to explain victories as well as losses. Even when advocates win in a case like Obergefell v. Hodges or Grutter v. Bollinger, the Court carefully cabins its opinion so as not to destabilize the social hierarchy. We illustrate this claim through a close examination of the use of social science in Obergefell. The Court disregarded evidence suggesting that same-sex couples and parents experience positive differences, as compared to heterosexuals, such as instilling greater respect for gender and sexual orientation equality in their children. The Court also asserted the innocence of opponents of same-sex marriage, ignoring evidence linking the denial of access to marriage to homophobia. In short, a movement to upend homophobic marriage laws was itself confined by homophobia, which influenced which arguments lawyers and Justices could articulate.
\end{abstract}

AUTHORS-Russell K. Robinson is the Distinguished Haas Chair in LGBT Equity and Professor of Law, University of California, Berkeley School of Law; David M. Frost is a Senior Lecturer in Social Psychology at University College London. We are grateful for helpful 
comments on earlier drafts from Ian Haney-López, Clare Huntington, Victoria Plaut, and participants at a faculty workshop of the University of Denver Law School. We thank Paris DeYoung and Jose Barragan for providing extensive research assistance, and Tyler Wolfe for providing additional assistance. Edna Lewis of the University of California, Berkeley Law Library was also very helpful.

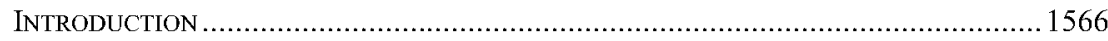

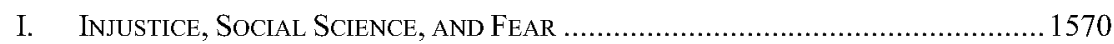

II. Bifurcating Gay and Lesbian Lives: Sameness v. Damage .....................1576

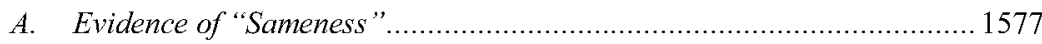

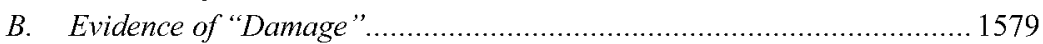

III. Selective Social Science at the Court: A Case Study of ObergefelL ....1582

A. Social Science in the Obergefell Amicus Briefs: A Systematic Review.....1583

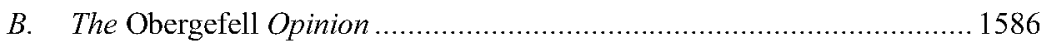

IV. Imagining a More Inclusive Marriage Equality Movement ....................1591

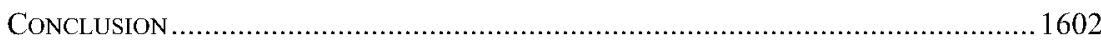

\section{INTRODUCTION}

The last five years have seen historic shifts in social justice movements that focus on race and sexual orientation. ${ }^{1}$ In 2013, a jury acquitted George Zimmerman of charges related to the shooting of Trayvon Martin, an unarmed African-American teenager whom he wrongly suspected to be a criminal. ${ }^{2}$ Three black women activists responded with a social media-fueled movement called \#BlackLivesMatter. ${ }^{3}$ Additional tragic deaths of unarmed African-Americans in 2014 and 2015 galvanized unrest in African-American communities (and beyond) and activism contesting police tactics such as racial profiling and excessive force. ${ }^{4}$ At the same time, marriage equality

\footnotetext{
1 See, e.g., Devon W. Carbado, From Stopping Black People to Killing Black People: The Fourth Amendment Pathways to Police Violence, 105 CALIF. L. REV. 125, 125 (2017) (arguing the period of 2014 to 2016 was highly significant in the history of U.S. race relations); Russell K. Robinson \& David M. Frost, The Afterlife of Homophobia, 60 ARIZ. L. REV. 213, 214, 224-26 (2018) (discussing Supreme Court developments regarding same-sex marriage from 2013 to 2015).

2 See Carbado, supra note 1, at 131 n.23.

3 Id.; see also Herstory, BLACK LIVES MATTER, https:/blacklivesmatter.com/about/herstory [https://perma.cc/LKE7-2ZVB]. Black Lives Matter is also notable because its leaders include prominent women, queer, and transgender people - a break from longstanding patterns of marginalization of such people in African-American politics. See id.

4 See id:; Liz Fields, After Walter Scott Killing, Black Lives Matter Movement Calls For Citizen Oversight of Police, VICE NEWS (Apr. 10, 2015, 11:25 AM), https://news.vice.com/article/after-walterscott-killing-black-lives-matter-movement-calls-for-citizen-oversight-of-police [https://perma.cc/9J95Y8GJ].
} 
activists and lawyers were building the cases that they hoped would secure a nationwide constitutional right to marry a partner of the same sex. ${ }^{5}$ In 2013, they persuaded the Court to invalidate part of the Defense of Marriage Act, a federal law refusing to recognize same-sex marriages. ${ }^{6}$ Two years later, the Court, in Obergefell v. Hodges, announced that every state had to license same-sex marriages, ${ }^{7}$ a decision viewed by many as the capstone of decades of lesbian, gay, bisexual, and transgender (LGBT) legal advocacy. ${ }^{8}$ By late 2016, however, both of these issues - marriage equality and police violence directed at African-Americans-would be swept off the front pages of newspapers by the unexpected election of Donald J. Trump as President. ${ }^{9}$ Although the Black Lives Matter (BLM) movement continues to organize and protest, it has, at present, left little mark on federal law. The battery of Supreme Court cases that rebuff the overwhelming majority of legal challenges to police misconduct remains very much intact. ${ }^{10}$ This disparity might lead a casual observer to think that LGBT people secured full legal equality in recent years, while African-Americans and other people of color continue to lose at the Supreme Court.

While there is truth to the divergent trajectories of African-Americans and LGBT claimants at the Supreme Court level, ${ }^{11}$ this Essay seeks to supplement and complicate that narrative. We argue that a "fear of too much

5 See, e.g., Ariel Levy, The Perfect Wife, NEW YORKER (Sept. 30, 2013), http:/www.newyorker.com/magazine/2013/09/30/the-perfect-wife [https://perma.cc/A8B4-RSCE] (describing the early development of the Windsor case, which struck down the Defense of Marriage Act).

${ }^{6}$ United States v. Windsor, 133 S. Ct. 2675, 2693 (2013) (identifying "strong evidence of [the Defense of Marriage Act] having the purpose and effect of disapproval of [same-sex married couples]"); $i d$. at 2694, 2696 (concluding that the statute "demeans the couple," "undermines" their relationship privately and publicly, "humiliates tens of thousands of children now being raised by same-sex couples" and thus violates the Fifth Amendment).

7 135 S. Ct. 2584, 2608 (2015).

8 See Robinson \& Frost, supra note 1, at 215 n.1 (describing media discourse on Obergefell).

9 As one BLM activist stated, "I think the media companies, vying for the very little brain space in people's minds, are reporting on what they think people want to hear about right now. And that's Trump." Janell Ross \& Wesley Lowery, Turning Away from Street Protests, Black Lives Matter Tries a New Tactic in the Age of Trump, WASH. POST (May 4, 2017), https:/www.washingtonpost.com/national/in-trumpsamerica-black-lives-matter-shifts-from-protests-to-policy/2017/05/04/a2acf37a-28fe-11e7-b60533413c691853_story.html [https://perma.cc/8SXE-6FN6].

${ }^{10}$ See, e.g., Carbado, supra note 1, at 125 ("Fourth Amendment law facilitates the space between stopping black people and killing black people."); see also id. at 130 ("African Americans often experience the Fourth Amendment as a system of surveillance, social control, and violence, not as a constitutional boundary that protects them from unreasonable searches and seizures.").

11 See generally Russell K. Robinson, Unequal Protection, 68 STAN. L. REV. 151 (2016) [hereinafter Robinson, Unequal Protection] (identifying "LGBT exceptionalism" in Supreme Court opinions and demonstrating that in that context LGBT plaintiffs have been more successful than women and people of color in recent years). 
justice" ${ }^{\prime 2}$ connects race and sexual orientation cases. Even when LGBT people win in cases like Obergefell, or underrepresented racial minorities win in affirmative action cases like Fisher v. University of Texas, the Court carefully cabins its opinions to preserve the social hierarchy with only incremental changes. ${ }^{13}$ Pressure to "play it safe" may operate at multiple levels: lawyers frame arguments to appeal to Justice Anthony Kennedy's conservative ideology; Justice Kennedy may refrain from articulating arguments that he fears will inflame the religious right; and liberal Justices may opt not to write separately and repudiate troubling aspects of Justice Kennedy's analysis for fear of losing his swing vote.

Marriage equality lawyers played this game by presenting predominantly white, middle-class, and "all-American" plaintiffs-people who were ultimately depicted by Justice Kennedy as "needing" to assimilate into marital norms rather than desiring to change them. ${ }^{14}$ We demonstrate that these lawyers selectively drew on social science, sidestepping studies suggesting positive differences between same-sex and different-sex couples and the transformational potential of same-sex relationships. Rather than telling a story of sexual minorities becoming like heterosexuals, the Court could have acknowledged that same-sex couples may offer valuable lessons for the broader society. By sketching the road not taken-an intersectional, more inclusive, and more LGBT-affirming marriage equality claim-our analysis suggests that the actual claim in Obergefell mainly mirrored the interests of the most privileged members of the class.

Moreover, in this Essay, we extend the story about racial justice by considering how affirmative action has fared at the Court during this time period. The Court's Fisher decision in 2016 surprised court observers by reaffirming Grutter v. Bollinger's diversity rationale and giving universities significant leeway to take race into account as part of a holistic review of applicants. ${ }^{15}$ Fisher, like Obergefell, is a notable victory and worthy of celebration. But affirmative action, standing alone, is a rather limited means of challenging racial subordination in education. It is no substitute for a systematic challenge to the de facto segregation and insufficient funding that

\footnotetext{
12 McCleskey v. Kemp, 481 U.S. 279, 339 (1987) (Brennan, J., dissenting).

13 See Reva Siegel, Why Equal Protection No Longer Protects: The Evolving Forms of StatusEnforcing State Action, 49 STAN. L. REV. 1111, 1113 (1997) (discussing "preservation-throughtransformation").

14 This legal strategy permitted the Obergefell Court to find that same-sex marriage was likely to strengthen, rather than weaken, "the institution of marriage" by expanding the ranks of married couples. 135 S. Ct. 2584, 2596 (2015). However, a more substantive means of strengthening marriage would have been to highlight and encourage the uniquely healthy dynamics exemplified by some same-sex couples and parents, which we discuss more fully below.

15136 S. Ct. 2198, 2210, 2214-15 (2016)
} 
hobble many of our nation's public schools. ${ }^{16}$ Nor does it require critical engagement with university admissions processes that effectively prioritize socioeconomically privileged applicants. Importantly, the corollary to Fisher's validation of affirmative action is the Court's ruling, in Schuette v. Coalition to Defend Affirmative Action, that states may amend their constitutions to forbid race-conscious policies without triggering meaningful judicial review. ${ }^{17}$ Thus, even though underrepresented people of color won in Grutter, Michigan voters quickly stripped them of this victory, and the Court provided no judicial recourse.$^{18}$ Our triangulation of affirmative action, criminal justice, and marriage equality suggests the Court's preference for affirming civil rights only when doing so will not dismantle entrenched social hierarchies. ${ }^{19}$

Our analysis builds on some first principles. First, science has sometimes been used to perpetuate the subordination of people of color, women, LGBT people, and many others. ${ }^{20}$ Second, courts sometimes invoke science in order to conceal their value choices in "objective" garb. ${ }^{21}$ For both of these reasons, scholars should subject scientific findings, and legal claims utilizing such findings, to critical analysis. A close examination of the Court's treatment of social science in certain leading equal protection cases also undercuts any assumption that the Court treats social science in a

16 See Parents Involved in Cmty. Schs. v. Seattle Sch. Dist. No. 1, 551 U.S. 701,867 (2007) (Breyer, J., dissenting) (describing school segregation as perpetuating "a caste system rooted in the institutions of slavery and 80 years of legalized subordination"); San Antonio Indep. Sch. Dist. v. Rodriguez, 411 U.S. $1,47,55$ (1973) (holding that Texas public education funding scheme did not violate equal protection by failing to distribute resources equitably).

17 Schuette v. Coal. to Defend Affirmative Action, Integration \& Immigrant Rights \& Fight for Equality by Any Means Necessary (BAMN), 134 S. Ct. 1623, 1638 (2014); see also Robinson, Unequal Protection, supra note 11, at 215-26 (demonstrating tension between Schuette and the Court's sexual orientation precedents).

18 Schuette, 134 S. Ct. at 1638 ("There is no authority in the Constitution of the United States or in this Court's precedents for the Judiciary to set aside Michigan laws that commit this policy determination to the voters."). Eight states have banned race-conscious policies: California, Washington, Michigan, Nebraska, Arizona, Oklahoma, Florida, and New Hampshire. See Halley Potter, What Can We Learn from States that Ban Affirmative Action, CENTURY FOUND. (June 26, 2014), https:/tcf.org/content/ commentary/what-can-we-learn-from-states-that-ban-affirmative-action [https:/perma.cc/K94D-S3U3].

19 See Robinson, Unequal Protection, supra note 11, at 228 (referring to the Court's Obergefell decision as granting only "equality on the cheap" to the marriage equality movement).

20 See, e.g., RONALD BAYER, HOMOSEXUALITY AND AMERICAN PSYCHIATRY: THE POLITICS OF DIAGNOSIS 49-50 (1981); DOROTHY ROBERTS, FATAL INVENTION: HOW SCIENCE, POLITICS, AND BIG BUSINESS RE-CREATE RACE IN THE TWENTY-FIRST CENTURY 23 -25 (2011); Clare Huntington, The Empirical Turn in Family Law, 118 CoLUM. L. REV. 227, 296-310 (2018). See generally Robinson \& Frost, supra note 1 (arguing that HIV-related public policies instill stereotypes about sex between men).

21 See, e.g., Roe v. Wade, 410 U.S. 113, 117 (1973) (looking to "medical and medical-legal history" to identify a right to terminate a pregnancy); Brown v. Bd. of Educ., 347 U.S. 483, 494 n.11 (1954) (invoking social psychology scholarship on internalized racism to justify invalidating laws that required racially-segregated public schools). 
uniform manner. We suggest that the Court's openness to social science in such litigation will depend on the extent to which its presentation threatens to unleash what the Court regards as "too much justice." When faced with competing bodies of social scientific discourse, we can expect the Court to emphasize the strand that minimally disrupts the status quo.

\section{INJUSTICE, SOCIAL SCIENCE, AND FEAR}

In this Part, we argue that a "fear of too much justice," particularly law reform efforts that would require the courts to restructure inequitable institutions, animates several leading civil rights cases. Importantly, this fear surfaces not only in cases in which the Court rejects the civil rights claim, but also those in which it rules in favor of a racial or sexual minority group. We argue that scholars who study how courts engage social science in civil rights cases must always keep these power dynamics in mind, as they are likely to shape how lawyers deploy social science and whether and how the Court engages with it. ${ }^{22}$

McCleskey v. Kemp ${ }^{23}$ serves as the Court's most controversial rejection of social science evidence, and it also represents perhaps the Court's most notorious criminal justice opinion. Warren McCleskey, an AfricanAmerican man from Georgia, was sentenced to death for his role in the murder of a white police officer. ${ }^{24}$ In order to show that race played a significant role in the state's decision to sentence him to death-and that this violated the Fourteenth and Eighth Amendments-McCleskey enlisted David Baldus, a professor who conducted a sophisticated empirical analysis on the Georgia capital sentencing regime. McCleskey's core equal protection claim was that Georgia valued the lives of Whites more than the lives of Blacks, and that a black person who was convicted of killing a white person was particularly likely to be sentenced to death. ${ }^{25}$ Baldus's study concluded that, "even after taking account of 39 nonracial variables, defendants charged with killing white victims were 4.3 times as likely to receive a death sentence as defendants charged with killing blacks. ${ }^{2} 6$

Even though "over half - 55\% —of defendants in white-victim crimes in Georgia would not have been sentenced to die if their victims had been

22 See Kelly J. Lynch, Best Friends? Supreme Court Law Clerks on Effective Amicus Curiae Briefs, 20 J.L. \& POL. 33, 65 (2004) (suggesting that amici have incentives to distort or ignore social science findings that are contrary to their position).

23481 U.S. 279 (1987).

24 Id. at $283-85$.

25 See id. at 287.

$26 I d$. 
black, ${ }^{, 27}$ and even though the Court had looked to statistical evidence in recent equal protection cases and Title VII cases ${ }^{28}$ the McCleskey majority dismissed Baldus's empirical evidence. ${ }^{29}$ McCleskey's use of the Baldus study to show systemic bias in Fulton County, Georgia, was inapt, the Court said, because it failed to "prove that the decisionmakers in his case acted with discriminatory purpose." ${ }^{30}$

McCleskey did not rely on science alone; he also drew on Georgia's well-documented history of racial antagonism and criminal laws that formally segregated offenses based on the race of the defendant and the victim. The Court derided this "historical evidence" as similarly irrelevant: "Although the history of racial discrimination in this country is undeniable, we cannot accept official actions taken long ago as evidence of current intent." ${ }^{\prime 31}$

The majority repeatedly adverted to the sweeping scope of McCleskey's claim and its capacity to unsettle the country's entire criminal justice system. ${ }^{32}$ Moreover, notes from the Justices' files suggest that the Court's denial of McCleskey's claim had less to do with any failings of the social science in the record and more to do with a fear that recognizing the

27 Id. at 326 (Brennan, J., dissenting).

28 Id. at 293-94 (citing Bazemore v. Friday, 478 U.S. 385, 400-01 (1986) (Brennan, J., concurring in part); Vill. of Arlington Heights v. Metro. Hous. Dev. Corp., 429 U.S. 252, 266 n.13 (1977)); see also Batson v. Kentucky, 476 U.S. 79, 97-98 (1986) (developing a framework for inferring racial discrimination that permits the use of statistical evidence).

29 The majority declared: "we assume the study is valid statistically ... . Our assumption that the Baldus study is statistically valid does not include the assumption that the study shows that racial considerations actually enter into any sentencing decisions in Georgia." McCleskey, 481 U.S. at 291 n.7; see also id. at 312-13 ("At most, the Baldus study indicates a discrepancy that appears to correlate with race.... The discrepancy indicated by the Baldus study is 'a far cry from the major systemic defects identified in Furman [v. Georgia]."').

${ }^{30} \mathrm{Id}$. at 292. Justice Lewis Powell pointed to Baldus's own testimony on the limits of what his study could prove. Baldus testified: "Models that are developed talk about the effect on the average. They do not depict the experience of a single individual. What they say, for example, [is] that on the average, the race of the victim, if it is white, increases on the average the probability ... [that] the death sentence would be given." Id. at 293 n.11.

${ }^{31} I d$. at 298 n.20. But see id. at 329-33 (Brennan, J., dissenting) (carefully laying out the copious historical evidence linking the findings of the Baldus study to Georgia's long history of penalizing interracial murder and rape differently depending on the race of the defendant and victim).

32 See id. at 292 ("In its broadest form, McCleskey's claim of discrimination extends to every actor in the Georgia capital sentencing process, from the prosecutor who sought the death penalty and the jury that imposed the sentence, to the State itself that enacted the capital punishment statute and allows it to remain in effect despite its allegedly discriminatory application."); id. at 293 ("McCleskey's claim that these statistics are sufficient proof of discrimination, without regard to the facts of a particular case, would extend to all capital cases in Georgia, at least where the victim was white and the defendant was black."); $i d$. at 297 ("McCleskey challenges decisions at the heart of the State's criminal justice system."); $i d$. at 314-15 ("McCleskey's claim, taken to its logical conclusion, throws into serious question the principles that underlie our entire criminal justice system.") 
bias in Georgia's death penalty regime would immerse the courts in critically evaluating the racial disparities that pervade the criminal justice system at multiple levels. ${ }^{33}$ Faced with this daunting task, the Court simply looked away from the equal protection problem. A similar "fear of too much justice, ${ }^{34}$ we argue, is apparent even in cases where the Court relied on social science to advance racial justice.

The most famous equal protection case is also the foremost example of the Court relying on social science. In Brown v. Board of Education, the Court declared policies that require racially segregated schools to be inherently unequal because, it said, they instill in black children "a feeling of inferiority as to their status in the community that may affect their hearts and minds in a way unlikely ever to be undone." ${ }_{35}$ The Court supported this claim with a footnote citing psychological scholarship by Kenneth B. Clark and others. ${ }^{36}$ At the same time, however, the Court deferred the question of implementation of its mandate to desegregate the schools. ${ }^{37}$ When the Court finally answered that question, its command that courts should proceed with "all deliberate speed"38 reflected ambivalence and trepidation. As Charles Ogletree explained, this phrase actually meant "slow." 39 The Brown Court's

33 The Court wrote that it would require "far stronger proof" before even requiring the state to respond to the allegation of racial bias. Id. at 296-97. Justice Antonin Scalia, however, in a memo to the conference of Justices, offered what might be a more candid explanation for the majority opinion (which he joined):

I disagree with the argument [in Justice Powell's draft opinion] that the inferences that can be drawn from the Baldus study are weakened by the fact that each jury and each trial is unique, or by the large number of variables at issue. And I do not share the view, implicit in the opinion, that an effect of racial factors upon sentencing, if it could only be shown by sufficiently strong statistical evidence, would require reversal. Since it is my view that unconscious operation of irrational sympathies and antipathies, including racial, upon jury decisions and (hence) prosecutorial decisions is real, acknowledged in the decisions of this court, and ineradicable, I cannot honestly say that all I need is more proof.

Erwin Chemerinsky, Eliminating Discrimination in Administering the Death Penalty: The Need for the Racial Justice Act, 35 SANTA CLARA L. REV. 519, 528 (1995) (reproducing the memorandum in full); see also Ian Haney-López, Intentional Blindness, 87 N.Y.U. L. REV. 1779, 1844-47 (2012) (examining McCleskey's dismissal of relevant evidence of bias).

34 McCleskey, 481 U.S. at 339 (Brennan, J., dissenting).

35347 U.S. 483,494 (1954).

${ }^{36} I d$. at 494 n.11. Numerous legal and social science scholars have criticized the underlying science and the Brown Court's decision to rely on it. See, e.g., Gwen Bergner, Black Children, White Preference: Brown v. Board, The Doll Tests, and the Politics of Self-Esteem, 61 AM. Q. 299, 309-314 (2009); Herbert Wechsler, Toward Neutral Principles of Constitutional Law, 73 HARV. L. REV. 1, 32-33 (1959); see also Lani Guinier, From Racial Liberalism to Racial Literacy: Brown v. Board of Education and the InterestDivergence Dilemma, 91 J. AM. HIST. 92, 100 (2004) (offering a related critique of Brown).

37 Brown, 347 U.S. at 495 ("[T]he formulation of decrees in these cases presents problems of considerable complexity.").

38 Brown v. Bd. of Educ., 349 U.S. 294, 301 (1955).

39 Charles J. Ogletree, Jr., All Deliberate Speed?: Brown's Past and Brown's Future, 107 W. VA. L. REV. 625, 628 (2005). 
"moral equivocation at a crucial moment [represented] a political backing off so as to leave the solution to the very states that had created the problem. This message of slowness was heeded across the country." 40

The Court's other major turn to social science in race-related equal protection cases came nearly fifty years later in Grutter v. Bollinger. ${ }^{41}$ In that 2003 affirmative action case, the Court reaffirmed the diversity rationale as articulated in Justice Lewis Powell's opinion in Regents of the University of California v. Bakke. ${ }^{42}$ The Grutter majority held that the University of Michigan Law School had a "compelling interest" in obtaining the educational benefits associated with a diverse study body. ${ }^{43}$ Thus, universities could take race into account in admitting students as one aspect of a broader, holistic commitment to diversity. In order to support its claim that diversity confers educational benefits, the Court cited "expert studies and reports entered into evidence at trial [and] numerous [scientific] studies" in the record, including those cited in an amicus brief by the American Educational Research Association. ${ }^{44}$

This victory was tempered by important limitations. First, the Court declined to rely on the interest in remedying past discrimination, which detached the rationale for affirmative action from the long history of racial subordination. By stressing that diversity-based policies benefit people of all different stripes - say, a white tuba player from Idaho- the Court deflected attention from and cloaked specific racial harms that do not extend to white tuba players. ${ }^{45}$ While the $\mathrm{McCleskey}$ opinion curtly dismissed the relevance of historical evidence of racial discrimination, ${ }^{46}$ the Grutter Court more deftly bracketed an engagement of our nation's ugly history of white supremacy in favor of a forward-looking and more "racially neutral" conception of diversity. As Kyneshawau Hurd \& Victoria C. Plaut argue in a related article in this Symposium Issue, the ostensibly neutral framing of "diversity benefits" may mask a focus on admitting people of color in order to enhance white students' classroom experiences. They cite scientific

${ }^{40} \mathrm{Id}$.

41539 U.S. 306 (2003).

42438 U.S. 265 (1978).

43539 U.S. at $328-29$.

44 Id. at 330 (citing Brief of the Am. Educ. Res. Ass'n et al. as Amici Curiae Supporting Respondents at 3, Grutter, 539 U.S. 306 (No. 02-241), 2003 WL 398292); see also id. ("These benefits are not theoretical but real."); Kyneshawau Hurd \& Victoria C. Plaut, Diversity Entitlement: Does Diversity Benefits Ideology Undermine Inclusion?, 112 NW. U. L. REV. 1605, 1612-13 (2018).

45 See, e.g., Derrick Bell, Diversity's Distractions, 103 ColuM. L. REv. 1622, 1622 (2003) (arguing that Grutter diverted attention from racial and socioeconomic subordination); Stephen M. Rich, What Diversity Contributes to Equal Opportunity, 89 S. CAL. L. REV. 1011, 1017-18 (2016).

46 See supra text accompanying notes $30-31$. 
research that raises questions about "whether the benefits of [interracial] contact extend equally across groups" or predominantly accrue to white students. ${ }^{47}$

Second, Grutter and the subsequent Fisher decisions ${ }^{48}$ are less consequential when put in their proper context. The number of slots that flow to underrepresented minorities because of race-conscious admissions policies are relatively few. ${ }^{49}$ Although preserving access for these few underrepresented minorities is important, such policies do not challenge the basic infrastructure of university admissions and the educational system that feeds students into universities and graduate schools. The second Fisher decision (Fisher II) appears to defer to what the Court regarded as fair procedures to determine admissions practices and to use them as a proxy for the question of whether taking race into account is truly necessary to achieve a "critical mass" of underrepresented students. ${ }^{50}$ This "stay the course" approach starkly contrasts with the destabilizing demands that the dissenting Justices would have levied on universities. In Fisher II, Justice Samuel Alito would have required the University of Texas to provide much more extensive and detailed empirical evidence, including determining exactly how many students benefited from taking race into account and in which classes they enrolled.51 In Grutter, Justice Clarence Thomas, joined in part by Justice Antonin Scalia, went ever further. They would have required the University of Michigan to choose between use of the LSAT, which buttresses its elite status, and its interest in racial diversity. ${ }^{52}$ These dissenters demonstrated a taste for invasive judicial intervention and would have wielded it to deter universities from adopting race-conscious policies. The Court majority eschewed these approaches, and both Grutter and Fisher $I I$ can be understood as deferring to the status quo. This is a victory for underrepresented minorities insofar as it suggests that at least as long as Justice Kennedy remains the swing vote, the Court may leave universities in peace to carry out race-conscious policies. However, the Justices in Fisher $I I$ and Grutter were fighting over a rather modest departure from "color-

\footnotetext{
47 Hurd \& Plaut, supra note 44, at 1623.

48 Fisher v. Univ., of Tex., 136 S. Ct. 2198 (2016) [hereinafter Fisher II; Fisher v. Univ. of Tex., 133 S. Ct. 2411, 2420-22 (2013) (holding the Fifth Circuit erred by deferring to university in conducting Court's narrow tailoring analysis).

49 See Goodwin Liu, The Causation Fallacy: Bakke and the Basic Arithmetic of Selective Admissions, 100 MiCH. L. REV. 1045, 1074 (2002).

${ }^{50} \mathrm{Cf}$. Fisher II, $136 \mathrm{~S}$. Ct. at 2215 ("It is the University's ongoing obligation to engage in constant deliberation and continued reflection regarding its admissions policies.").

51 Id. at 2216, 2222, 2226-27, 2241 (Alito, J., dissenting).

52 Grutter v. Bollinger, 539 U.S. 306, 356 n.4, 369-70 (2003) (Thomas, J., concurring in part and dissenting in part).
} 
blind" admissions policies that disproportionately benefit affluent and middle-class students. ${ }^{53}$ The Court majority declined to call into question universities" general reliance on standardized tests and "legacy" admissions, ${ }^{54}$ two practices that typically benefit white upper- and middleclass students. The Kennedy-led majority has shown little interest in questioning dominant conceptions of "merit" as embodied in standardized tests. ${ }^{55}$ In Fisher II, some social science scholars filed briefs in order to show the need for policies that counteract the flawed and biased nature of standardized tests and other structural conditions, such as "stereotype threat," that make students of color vulnerable and depress their academic performance. ${ }^{56}$ But the Court majority ignored this body of science, reinscribing the "diversity benefits" rationale from Grutter and generally avoiding a discussion of racial discrimination. ${ }^{57}$

This critical analysis of race equal protection precedents has tried to show that, despite their disparate outcomes and differences in receptivity to social science, McCleskey, Brown, Grutter, and Fisher share significant connective tissue, namely a fear of dramatic social transformation. ${ }^{58}$ Ever since Brown's unsuccessful attempt to reform the public school system, the Court tends to shrink from extensive engagement with systems that consistently disadvantage minorities. This context helps explain why the Court refused to open the door to wide-scale reform of the criminal justice

53 Bell, supra note 45 , at 1622 ("The tremendous attention directed at diversity programs diverts concern and resources from the serious barriers of poverty that exclude far more students from entering college than are likely to gain admission under an affirmative action program.").

${ }^{54}$ Fisher II, $136 \mathrm{~S}$. Ct. at 2240 (Alito, J., dissenting) (describing what Justice Alito called a secretive legacy admissions process at the University of Texas).

55 See Bell, supra note 45 , at 1632 ("Diversity then is less a means of continuing minority admissions programs in the face of widespread opposition than it is a shield behind which college administrators can retain policies of admission that are woefully poor measures of quality, but convenient vehicles for admitting the children of wealth and privilege.").

56 E.g., Brief of Experimental Psychologists as Amici Curiae in Support of Respondents at 23-25, Fisher II, 136 S. Ct. 2198 (No. 14-981), 2015 WL 6774020 (arguing that stereotype threat depresses standardized test scores and GPAs for underrepresented minorities, thus making them flawed measures of merit); see also Hurd \& Plaut, supra note 44, at 1616-19. (summarizing briefs in the Fisher cases).

57 Cf. Bell, supra note 45, at 1625 (arguing that Justice Sandra Day O'Connor found the policy in Grutter acceptable because it "minimize[d] the importance of race while offering maximum protection to whites")

58 See also Pers. Adm'r of Mass. v. Feeney, 442 U.S. 256, 278 (1979) (expressing concern that striking down a veterans hiring preference as an equal protection violation might require the Court to confront gender-based "enlistment policies of the Armed Forces"); Washington v. Davis, 426 U.S. 229, 248 (1976) ("A rule that a statute designed to serve neutral ends is nevertheless invalid, absent compelling justification, if in practice it benefits or burdens one race more than another would be far-reaching and would raise serious questions about, and perhaps invalidate, a whole range of tax, welfare, public service, regulatory, and licensing statutes that may be more burdensome to the poor and to the average black than to the more affluent white."). 
system in McCleskey and why marriage equality, which we consider in the next Part, was an appealing opportunity for judicial intervention.

\section{Bifurcating GAy And LeSbian Lives: SAmEness V. DAmage}

During the Supreme Court oral argument in Hollingsworth v. Perry, ${ }^{59}$ which concerned the constitutionality of California's Proposition 8's ban on same-sex marriage, Chief Justice John Roberts identified a tension between two claims made by lawyers representing same-sex couples seeking the right to marry. ${ }^{60}$ His exchange with Solicitor General Donald Verrilli sets up our exploration of the social science supporting these competing claims:

CHIEF JUSTICE ROBERTS: [I]t seems to me that your position that you are supporting is somewhat internally inconsistent. We see the argument made that there is no problem with extending marriage to same-sex couples because children raised by same-sex couples are doing just fine and there is no evidence that they are being harmed. And the other argument is Proposition 8 harms children by not allowing same-sex couples to marriage [sic]. Which is it?

GENERAL VERRILLI: Well, I -- I think what Proposition 8 does is deny the long-term stabilizing effect that marriage brings. That's -- that's the argument for -- for marriage, that --

CHIEF JUSTICE ROBERTS: But you also tell me there has been no harm shown to children of same-sex couples.

GENERAL VERRILLI: California -- there are 37,000 children in same-sex families in California now. Their parents cannot marry and that has effects on them in the here and now. A stabilizing effect is not there. When they go to school, they have to -- you know -- they don't have parents like everybody else's parents. That's a real effect, a real cost in the here and now. ${ }^{61}$

The following discussion provides the scientific context that gave rise to the apparent tension between the claim that laws denying them access to marriage harm same-sex couples and their children, and yet, the relationships and children of same-sex couples are no less "healthy" than heterosexuals". Over the past several decades, research in the social and health sciences on sexual minority health and well-being-stemming mainly from psychology, sociology, and public health-has grown exponentially. For the purposes of this analysis, we divide findings from this broad field of research into two

\footnotetext{
59570 U.S. 693 (2013).
}

${ }^{60}$ Transcript of Oral Argument at 61-62, Hollingsworth, 570 U.S. 693 (No. 12-144); see also David M. Frost, Redemptive Framings of Minority Stress and their Association with Closeness in Same-Sex Relationships, 13 J. COUPLE \& RELATIONSHIP THERAPY 219 (2014) (discussing the tension between bodies of social science evidence scholarship making these claims).

61 Transcript of Oral Argument, supra note 60, at 61-62. 
streams in order to highlight the benefits and challenges that social science evidence has posed for policy discussions around marriage equality in the United States. First, we consider how research evidence has been fed into a discourse of "sameness" in an attempt to demonstrate that sexual minority individuals and couples are no different from their heterosexual counterparts on key health and well-being outcomes. Second, we discuss another stream of research which contributes to a discourse of "minority stress" or "damage." This stream points to the ways in which structural (e.g., discriminatory laws and policies) and interpersonal (e.g., workplace and familial discrimination) stigma can be damaging to the health and well-being of sexual minorities, as well as their relationships and families.

From a social science perspective, discourses like these can be problematic, because they individually fail to represent the whole of sexual minorities' lived experiences. However, isolating findings within these separate discourses has proven useful at various points within policy change efforts. After providing a brief review of these two streams of research, the next Section will discuss the tensions that have emerged as a result of using evidence from the social sciences in marriage equality efforts.

\section{A. Evidence of "Sameness"}

Perhaps the most influential research findings on the status of sexual minorities in the mental health literature emerged from a 1957 study conducted by Evelyn Hooker, which demonstrated that gay men's responses to a popular projective technique used in the diagnosis of mental health problems were not distinguishable from the responses of heterosexual men. ${ }^{62}$ Hooker's research provided a turning point because she studied highly functional men in the general population unlike most prior research, which had focused on unrepresentative samples, such as "homosexuals in prisons, mental hospitals, or the disciplinary barracks of the armed services." ${ }^{63}$ The majority of her subjects had successfully maintained long-term romantic relationships. ${ }^{64}$ Hooker's foundational finding of sameness ultimately played a pivotal role in the effective removal of homosexuality from the American Psychiatric Association's Diagnostic and Statistical Manual for Mental Disorders (DSM), thereby winning a major battle in efforts to "depathologize" homosexuality within the medical community. ${ }^{65}$

\footnotetext{
62 Evelyn Hooker, The Adjustment of the Male Overt Homosexual, 21 J. OF PROJECTIVE TECHNIQUES 18 (1957).

63 BAYER, supra note 20 , at $49-50$.

64 Id. at 52.

65 For historical reviews, see id:; Jack Drescher, Out of DSM: Depathologizing Homosexuality, 5 BEHAV. SCI. 565 (2015). Ronald Bayer's fascinating historical account makes clear that Hooker and
} 
This approach mirrors the courts' efforts to depathologize same-sex relationships from the standpoint of marriage policy, which-until recently-was restricted to male-female couples in the majority of U.S. states. Specifically, findings from decades of studies using between-groups designs, which compare same-sex male and female couples with differentsex couples, became especially useful in documenting the lack of meaningful differences between the groups on a variety of important relational outcomes.

For example, Lawrence Kurdek's influential line of research detected no differences between same-sex male and female cohabiting couples and different-sex married couples. Across two longitudinal studies involving eight annual assessments with hundreds of couples, Kurdek observed no differences in important benchmarks surrounding psychological adjustment and relationship quality. ${ }^{66}$ The lack of differences observed in these data led Kurdek to conclude that "there is no evidence that gay partners and lesbian partners were psychologically maladjusted, that they had high levels of personality traits that predisposed them to relationship problems, that they had dysfunctional working models of their relationships, [or] that they used ineffective strategies to resolve conflict." ${ }^{67}$ Other studies have also found similarities between individuals in same-sex and different-sex couples in the meanings and importance they place on the role of intimacy and relationships in their lives. ${ }^{68}$ These are just some illustrative examples of many studies that find no differences between same-sex and different-sex couples in between-

the American Psychiatric Association were keenly aware of the political stakes of this research. Hooker was in conversation with gay rights groups such as the Mattachine Society and found some of her subjects through them. See BAYER, supra note 20, at 50, 53. Gay rights activists assailed psychiatry's role in stigmatizing their identities by disrupting the Association's annual conferences, picketing lectures by prominent psychiatrists who fought to preserve the pathologizing conception of homosexuality, and helping closeted psychiatrists to come out to their colleagues and articulate the injuries their profession was inflicting on them. Id. at $92,98-99,102,109$. While early gay rights groups had deferred to psychiatry's claim of expertise, an increasingly adamant cohort of (nonscientist) gay rights leaders in the late 1960 s and early 1970 s insisted that "We are the true authorities on homosexuality whether we are accepted as such or not" and "gay is good." Id. at 82-83, 91 .

${ }^{66}$ Lawrence A. Kurdek, Are Gay and Lesbian Cohabiting Couples Really Different from Heterosexual Married Couples?, 66 J. MARRIAGE \& FAM. 880 (2004) [hereinafter Kurdek, Cohabitating Couples]; Lawrence A. Kurdek, What Do We Know About Gay and Lesbian Couples?, 14 CuRRENT DIRECTIONS IN PSYCHOL. SCI. 251 (2005) [hereinafter Kurdek, What Do We Know].

67 Kurdek, Cohabitating Couples, supra note 66, at 896.

68 See, e.g., David M. Frost \& Kelly A. Gola, Meanings of Intimacy: A Comparison of Members of Heterosexual and Same-Sex Couples, 15 ANALYSES OF SOC. ISSUES \& PUB. POL'Y 382 (2015). 
group studies ${ }^{69}$ and the health and adjustment of children of same-sex parents. $^{70}$

\section{B. Evidence of "Damage"}

In contrast to the early research of psychologists and psychiatrists aimed at depathologizing homosexuality, a sizable number of studiestypically conducted by public health and social epidemiology scholarshave demonstrated that sexual minority populations experience higher levels of psychological distress and disorder compared to heterosexuals. ${ }^{71}$ These inequalities in mental health do not, however, contradict the arguments of earlier psychologists and psychiatrists that homosexuality is not a symptom of pathology. Instead, the disadvantaged social status afforded to sexual minorities relative to heterosexuals and the persistence of social stigma surrounding sexual minority identities and same-sex sexuality is theorized to cause these persistent health inequalities. In other words, the root of these differences lies in the social marginalization of sexual minorities and is not a property of a sexual minority identity per se. ${ }^{72}$

Minority stress theory seeks to explain how social stress, stemming from disadvantaged social status, explains the continued existence of sexualorientation-based health disparities. The minority stress framework articulates specific and unique minority stressors that sexual minority individuals are potentially exposed to as a result of their stigmatized social status, and posits that these unique stressors put sexual minorities at greater risk for mental and physical health problems relative to heterosexuals. ${ }^{73}$ These stressors include event-based forms of discrimination (i.e., prejudice events), "non-event" stress (e.g., failing to attain important events, such as marriage, by a certain age), as well as chronic and everyday forms of

69 For comprehensive reviews, see Kurdek, What Do We Know, supra note 66, and Letitia A. Peplau \& Adam W. Fingerhut, The Close Relationships of Lesbians and Gay Men, 58 ANN. REV. PSYCHOL. 405 (2007).

70 See Timothy J. Biblarz \& Judith Stacey, How Does the Gender of Parents Matter?, 72 J. MARRIAGE \& FAM. 3 (2010).

71 For meta analyses, see, for example, Michael King et al., A Systematic Review of Mental Disorder, Suicide, and Deliberate Self Harm in Lesbian, Gay and Bisexual People, 8 BMC PSYCHIATRY 70 (2008), and Ilan Meyer, Prejudice, Social Stress, and Mental Health in Lesbian, Gay, and Bisexual Populations: Conceptual Issues and Research Evidence, 129 PSYCHOL. BULL. 674 (2003).

72 See generally Meyer, supra note 71 (stating that stigma, prejudice, and discrimination are forms of minority stress which explain the disparities in mental health problems faced by lesbian, gay, and bisexual populations).

${ }^{73}$ See id; Ilan H. Meyer \& David M. Frost, Minority Stress and the Health of Sexual Minorities, in HANDBOOK OF PSYCHOLOGY AND SEXUAL ORIENTATION 252, 252-66 (Charlotte J. Patterson \& Anthony R. D'Augelli eds., 2013). 
discrimination (i.e., being treated with less courtesy, people acting as if they are afraid of you). ${ }^{74}$

These externally generated forms of differential treatment from society can lead to psychological forms of stigma-related stress, such as entering into situations expecting to be discriminated against (i.e., expectations of rejection), the need to manage how "out" one is to other people across various contexts in life (i.e., stigma concealment), and the application of societal devaluation of sexual minorities to one's own sense of self (i.e., internalized stigma). Indeed, some studies have shown that when statistically controlling for exposure to various forms of minority stress, differences in mental health between heterosexuals and sexual minorities are substantially attenuated or no longer detectable. ${ }^{75}$

A growing body of research shows that not only do these forms of stress burden people as individuals, they also can harm sexual minorities' efforts to seek and maintain romantic relationships. ${ }^{76}$ For example, people in samesex relationships, like their sexual minority counterparts who are single, experience discrimination as well as daily hassles and harassment, ${ }^{77}$ and these daily struggles can burden their relationships. There is also some evidence to suggest that, as compared to their single peers, sexual minorities in same-sex relationships might be exposed to more stress associated with being rejected and misunderstood by other people in their lives, particularly

74 See Meyer, supra note 71, at 676-77. See generally David M. Frost \& Allen J. LeBlanc, Nonevent Stress Contributes to Mental Health Disparities Based on Sexual Orientation: Evidence from a Personal Projects Analysis, 84 AM. J. ORTHOPSYCHIATRY 557 (2014) (exploring non-event stress).

75 See Vickie M. Mays \& Susan D. Cochran, Mental Health Correlates of Perceived Discrimination Among Lesbian, Gay, and Bisexual Adults in the United States, 91 AM. J. PUB. HEALTH 1869 (2001); Frost \& LeBlanc, supra note 74.

76 See generally David Matthew Doyle \& Lisa Molix, Social Stigma and Sexual Minorities Romantic Relationship Functioning: A Meta-Analytic Review, 41 PERSONALITY \& SOC. PSYCHOL. BULL. 1363 (2015) (conducting review of thirty-five studies and concluding that social stigma against sexual minorities is associated with impaired relationship outcomes); Sharon S. Rostosky \& Ellen D.B. Riggle, Same-Sex Relationships and Minority Stress, 13 CURRENT OPINION IN PSYCHOL. 29 (2017) (reviewing research on minority stress and same-sex relationships).

77 See generally Lisa Diamond, The Intimate Same-Sex Relationships of Sexual Minorities, in THE Cambridge Handbook of Personal Relationships 293 (Anita L. Vangelisti \& Daniel Perlman eds., 2006) (providing overview of research on same-sex relationships, including issues of stigmatization and relationship dynamics and satisfaction); Robert-Jay Green \& Valory Mitchell, Gay and Lesbian Couples in Therapy: Minority Stress, Relational Ambiguity, and Families of Choice, in CLINICAL HANDBOOK OF COUPLE THERAPY 662 (Alan S. Gurman ed., 4th ed. 2008) (describing the unique challenges facing samesex couples, including minority stress, relational ambiguity, and developing a social support network); Peplau \& Fingerhut, supra note 69 (reviewing empirical research on same-sex couples, including the impact of societal prejudice and discrimination on same-sex partners); Rostosky \& Riggle, supra note 76 (same). 
by their families of origin. ${ }^{78}$ Moreover, societal stigma surrounding same-sex relationships can also be uniquely internalized, contributing to feelings of internalized homophobia among people in same-sex relationships ${ }^{79}$ which has been shown to be particularly detrimental to relationship quality among sexual minority individuals. ${ }^{80}$ These interpersonal stressors, along with other forms of discrimination and victimization, are associated with decreased relationship quality. ${ }^{81}$

Why do these competing bodies of scholarship matter? Each of the "damage" and "sameness" discourses is problematic if presented alone, because isolating one or the other fails to represent the whole of sexual minorities' lived experiences. ${ }^{82}$ As LGBT people, we may have the same basic desires and life goals as heterosexuals and yet face unique forms of stress as we seek to achieve those goals. ${ }^{83}$ These barriers extend far beyond the availability of a marriage license, and courts should know that. Judges should make decisions with a full understanding of LGBT people's lives, not just the slivers that lawyers sometimes choose to serve up to them. Instead, lawyers, policymakers, and scholars sometimes highlight one body of research while ignoring or glossing over the other. ${ }^{84}$ In the case of marriage equality, we worry that the lawyers' strategic choice to magnify sameness may be dangerous. The appeal to sameness may implicitly suggest that if same-sex couples and parents were not able to achieve the same outcomes

78 See Robin J. Lewis et al., An Empirical Analysis of Stressors for Gay Men and Lesbians, 42 J. HoMOSEXUALITY 63, 77 tbl.7 (2002).

79 See, e.g., David M. Frost \& Ilan H. Meyer, Internalized Homophobia and Relationship Quality Among Lesbians, Gay Men, and Bisexuals, 56 J. COUNSELING PSYCHOL. 97, 105 (2009).

${ }^{80}$ See Kimberly F. Balsam \& Dawn M. Szymanski, Relationship Quality and Domestic Violence in Women's Same-Sex Relationships: The Role of Minority Stress, 29 PSYCHOL. WOMEN Q. 258 (2005); Eli Coleman et al., Sexual and Intimacy Dysfunction Among Homosexual Men and Women, 10 PSYCHIATRIC MED. 257 (1992); Katie M. Edwards \& Kateryna M. Sylaska, The Perpetration of Intimate Partner Violence Among LGBTQ College Youth: The Role of Minority Stress, 42 J. YOUTH \& ADOLESCENCE 1721 (2013)

81 See generally Doyle \& Molix, supra note 76 (surveying research and concluding that minority stress has a negative effect on same-sex relationship outcomes); Rostosky \& Riggle, supra note 76 (same).

82 Our related article provides a fuller description of the bifurcation of LGBT identity and the government's inordinate focus on "damage" in the context of HIV risk. See Robinson \& Frost, supra note 1 .

83 See David M. Frost, Similarities and Differences in the Pursuit of Intimacy Among Sexual Minority and Heterosexual Individuals: A Personal Projects Analysis, 67 J. SOC. ISSUES 282 (2011) (showing that sexual minorities experience more barriers and devaluation to their relationship goals compared to heterosexuals); Frost \& LeBlanc, supra note 74 (finding that the experience of struggling with social barriers to achieving one's relationship goals partially explains why sexual minorities have poorer mental health than heterosexuals).

84 For an astute framework for courts and policymakers' use of social science evidence in the family law context, see Clare Huntington, The Empirical Turn in Family Law, 118 COLUM. L. REV. 227, 296310 (2018). 
as heterosexuals, it would be their fault and they would be unworthy of equal protection. Yet, as Clare Huntington has written, "Evidence on unequal outcomes for different demographic groups may be accurate, but the underlying conditions that create the family situations are often the result of systemic discrimination and inequality. Thus, using empirical evidence about poor outcomes to justify legal rules inflicts a second act of discrimination." ${ }_{85}$ The marriage equality movement's unmitigated embrace of sameness raises the risk of weakening Obergefell if scientific findings ultimately suggest adverse outcomes for same-sex couples and families. ${ }^{86}$ This strategic decision to downplay discrimination for short-term gain may come back to haunt the LGBT community in the long term. ${ }^{87}$

In the next Part, we first analyze the briefs in Obergefell to determine the extent to which they engaged these bodies of social science. We then turn to the Obergefell majority opinion to trace how the themes of sameness and minority stress surfaced even when the Court did not explicitly cite the briefs or the underlying studies. We follow that analysis in Part IV, which considers the road not taken, namely, a more inclusive and LGBT-affirming conceptualization of the marriage equality claim.

\section{Selective Social ScIENCE AT THE Court: A CASE STUDY OF OBERGEFELL}

This Part provides a close examination of the use of social science in the Obergefell case to demonstrate how lawyers and judges may selectively draw on science to question or acquiesce to social hierarchy. First, we review the briefs filed in Obergefell to make manifest the broad sweep of the scientific evidence that was put before the Justices. Second, we show how the majority opinion drew on certain concepts from the scientific literature, while notably ignoring or downplaying others. Ultimately, we criticize the opinion for minimizing the minority stress experienced by many sexual minorities and denying that homophobia motivated states' refusal to let same-sex couples marry. We also lament the opinion's failure to transcend a

85 Id. at 293; see supra text accompanying note 75 (discussing studies that found that after statistically controlling for exposure to various forms of minority stress, differences in mental health between heterosexuals and sexual minorities were no longer detectable).

86 Recall that the psychological evidence that the Court invoked in Brown suffered grave methodological attacks. See supra note 36.

87 In the race context, the Court has recognized the wrongfulness of using societal discrimination as a justification for denying fundamental rights. See, e.g., Palmore v. Sidoti, 466 U.S. 429, 433 (1984) (acknowledging that granting custody of a white child to a white mother who had married a black man would expose the child to discrimination but declaring: "[p]rivate biases may be outside the reach of the law, but the law cannot, directly or indirectly, give them effect"). In this regard, greater attention to race would have bolstered LGBT rights. 
sameness framework and consider ways in which same-sex couples may differ from heterosexual couples in beneficial ways.

\section{A. Social Science in the Obergefell Amicus Briefs: A Systematic Review}

Assisted by a team of research assistants, we reviewed all of the briefs in Obergefell to understand the extent to which the various players in the case engaged sameness and minority stress literatures. Two research assistants with prior experience conducting qualitative research read and coded all of the party briefs and amicus briefs submitted in the Obergefell case. Before coding a brief, the research assistant would look to the list of "Other Authorities" in the brief's table of contents. This list served as a starting point to give the research assistant a general idea of how heavily a brief relied on scientific research and where that research was likely to be found in the brief. The assistant would then read the brief and consider the context in which each scientific authority was cited.

Only scientific studies, and authorities that made claims based on cited scientific studies, were coded and included in subsequent analysis. We leveraged the scientific reports to provide a comparative measure of the briefs' relative attention to various bodies of social science research. We evaluated the text of the brief in order to determine whether the lawyers cited a study to advance a particular claim. ${ }^{88}$ These studies were initially coded based on four categories: (1) sameness, (2) damaging effects of minority stress, (3) positive difference, and (4) other science. "Sameness" studies are those that include references to how LGBT individuals, same-sex couples, or gays and lesbians are similar to heterosexual individuals-for example, studies that show that same-sex parents are just as successful at parenting as heterosexual individuals. "Damaging effects of minority stress" studies are those that include references to LGBT experiences of stigma, prejudice, and LGBT discrimination (i.e., minority stressors) and consider how minority stressors impact the physical or mental health of LGBT people. "Positive difference" studies are those that include references to how LGBT individuals are different, in a beneficial way, from heterosexual individuals - for example, studies that show studies show that same-sex parents are more likely than different-sex parents to instill in their children respect for gender and sexual orientation equality. The "other science" category was a catchall category for any cited scientific study that did not fit into any of the other enumerated categories. Any study that was difficult to

${ }^{88}$ One limitation of this science-focused methodology is that it did not allow us to measure the amount of text in a brief that was devoted to a particular body of research. However, there is no reason to believe that our primary emphasis on scientific citations, rather than text, favored one body of research over another. 
properly sort into one of the mentioned categories was flagged by the research assistants as a "judgment call" and reviewed by the lead researchers. The data collected by both research assistants were aggregated and descriptive statistics were calculated.

After an initial review of all of the briefs, we decided to focus on the briefs filed by the parties themselves and those filed by scientific organizations, as research suggests that these briefs are among those most likely to be read by Supreme Court Justices and clerks and to wield influence in the Court's decisionmaking. ${ }^{89}$ Recognizing that not all research on minority stress is focused on its damaging effects on health, we expanded our definition of minority stress, which resulted in a fifth category, (5) experiences of minority stress. "Experiences of minority stress" studies are those with any reference to stigma, prejudice, and discrimination against LGBT people, with or without a reference to how that discrimination impacts the physical or mental health of LGBT people. The research assistants then recoded all of the briefs to account for this new code. We reviewed the coding periodically and provided feedback to refine the coding.

Our review of the briefs indicates that the parties cited scientific studies sparingly, but when they cited social science, they favored sameness findings. Half of the parties' scientific citations (23 of 46 citations) made sameness arguments. By comparison, just $17 \%$ of the parties' scientific citations discussed minority stress. ${ }^{90}$ None of the parties' scientific citations asserted positive differences of same-sex relationships.

Perhaps the most influential brief of those filed by scientific authorities was from the American Psychological Association (APA), joined by the American Psychoanalytic Association, the National Association of Social Workers, the American Medical Association (AMA), and several other health-related organizations (for simplicity, we will refer to this as the "APA

89 See, e.g., Kathleen E. Hull, The Role of Social Science Expertise in Same-Sex Marriage Litigation, 13 ANN. REV. L. \& SOC. SCI. 471, 473 (2017) (discussing finding that briefs with social science "merited special consideration" among Supreme Court law clerks); Lynch, supra note 22 (studying Supreme Court clerks' use of briefs and noting that parties' briefs generally garner more attention than the typical amicus brief and found that a significant number of clerks consider briefs filed by medical and scientific authorities to be influential). Lynch's study concluded that $54 \%$ of clerks stated that briefs citing social science receive special attention, and a significant number of clerks specifically mentioned the American Psychological Association (APA) and American Medical Association (AMA) as influential amicus filers. Id. at 50-51, 66. However, one quarter of clerks said that they give such briefs less attention, and the people in this group tended to have clerked for Justices Thomas and Scalia. See id. at 66-68. Lynch's study also suggests "a credible public interest or research organization is much better positioned to provide social science findings than a typical litigant." Id. at 67.

${ }^{90}$ In our ultimate findings, we aggregate citations coded as "damaging effects of minority stress" and those coded as "experiences of minority stress" into a single category, which we call simply "minority stress." 
brief"). ${ }^{91}$ Of 115 citations to scientific authorities in the APA brief, $49.57 \%$ (57 citations) made sameness claims-roughly the same percentage of the parties' citations that made sameness arguments. ${ }^{92}$ Just $4.35 \%$ (5 citations) concerned minority stress, and 2.61\% (3 citations) raised positive differences. The American Sociological Association (ASA) filed another prominent brief. ${ }^{93}$ In the ASA brief, 46.67\% (21 of 45) of the scientific citations concerned sameness, while $4.44 \%$ ( 2 citations) concerned minority stress, and none concerned positive differences ${ }^{94} \mathrm{~A}$ brief by the American Public Health Association (APHA) may have served as a counterweight in that it featured more citations discussing minority stress $(46.55 \%, 27$ of 58 citations) than sameness $\left(10.34 \%, 6\right.$ citations) ${ }^{95}$ Figure 1 below summarizes our findings.

It is of course always difficult to know whether and how briefs influence Supreme Court Justices. The parties and leading scientific organizations such as the APA, AMA, and ASA converged on sameness studies and minimized discussion of minority stress and positive differences. However, the APHA, which is another leading health organization, might have provided a crucial corrective to what we consider to be an overemphasis on sameness and downplaying of ongoing discrimination and its effects. In the next Section, we discuss the Obergefell majority opinion and find that, like the parties and the APA, it said far more about sameness than minority stress and completely ignored positive differences..$^{96}$

\footnotetext{
91 See Brief of the American Psychological Association et al. as Amici Curiae in Support of Petitioners, Obergefell v. Hodges, 135 S. Ct. 2584 (2015) (Nos. 14-556, 14-562, 14-571, 14-574), 2015 WL 1004713. Lynch's study of Supreme Court clerks suggests that collaborative scientific briefs such as this may be particularly effective. See Lynch, supra note 22, at 58-59.

92 See supra text accompanying note 90 .

93 See Brief of the American Sociological Association as Amicus Curiae Supporting Petitioners, Obergefell, 135 S. Ct. 2584 (Nos. 14-556, 14-562, 14-571, 14-574), 2015 WL 1048442.

94 See id.

95 See Brief of Amici Curiae American Public Health Association and Whitman-Walker Health in Support of Petitioners, Obergefell, 135 S. Ct. 2584 (Nos. 14-556, 14-562, 14-571, 14-574), 2015 WL 1022680 . A brief by the Cato Institute also favored minority stress, although it contained fewer overall uses of science than the briefs by the APA, ASA, and APHA. See Brief of Amici Curiae Cato Institute et al. in Support of Petitioners, Obergefell, 135 S. Ct. 2584 (Nos. 14-556, 14-562, 14-571, 14-574), 2015 WL 1062557.

96 By contrast, the APA brief contained a few citations referencing positive differences. See Brief of the American Psychological Association et al., supra note 91.
} 
Figure 1: Social ScIENCE IN THE OBERGEFELL AMICUS BRIEFS

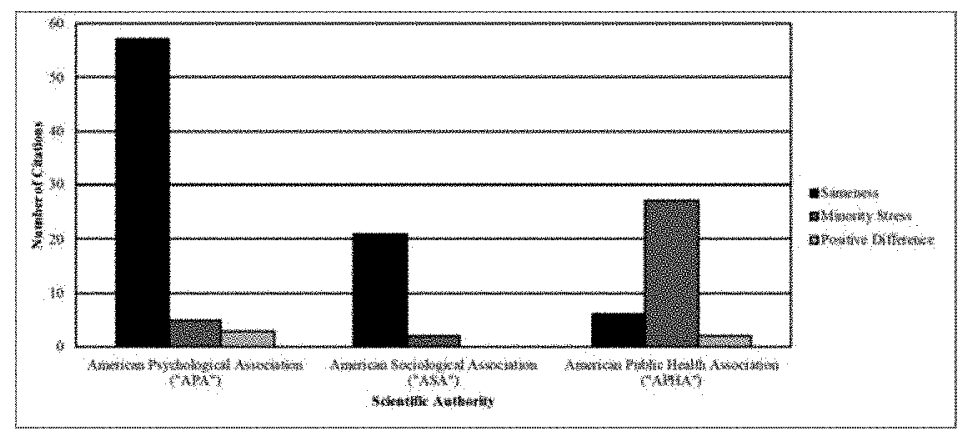

\section{B. The Obergefell Opinion}

The core of the Supreme Court's analysis in Obergefell asked whether the reasons why marriage is essential for heterosexuals also apply to samesex couples. This framing basically inquired whether same-sex couples are similarly situated to heterosexuals with respect to marriage ${ }^{97}$ By evaluating four benefits of marriage, the majority concluded that "the reasons marriage is fundamental under the Constitution apply with equal force to same-sex couples."98 These four benefits are the following: (1) marriage as an expression of personal autonomy, (2) marriage as a unique opportunity, (3) marriage as a means of protecting children and family, and (4) marriage as a central social institution. As to the first benefit, Justice Kennedy wrote, "the right to personal choice regarding marriage" is an inherent aspect of autonomy "for all individuals." 99 As to the second benefit, the Court emphasized that marriage constitutes a two-person union of singular importance to individuals. ${ }^{100}$

The Court's first reference to harm arising from discrimination came with respect to its discussion of marriage's third benefit: it "safeguards children and families." 101 Justice Kennedy stated that marriage provides social "recognition," "material" benefits, and "legal structure" to the couple and their family. ${ }^{102} \mathrm{He}$ observed that "all parties agree" that many same-sex couples provide loving families for their children. ${ }^{103}$ And, relying on

\footnotetext{
97 See 135 S.Ct. 2584, 2599 (2015) (stating that the Court is "assessing whether the force and rationale of [marriage precedents such as Loving v. Virginia] apply to same-sex couples").

$98 \mathrm{Id}$.

99 Id. (quoting Zablocki v. Redhail, 434 U.S. 374, 384 (1978)).

100 See id. (" $[\mathrm{D}]$ ecisions concerning marriage are among the most intimate that an individual can make." (citations omitted)).

101 Id. at 2600.

102 Id.

${ }^{103} I d$.
} 
demographer Gary Gates's amicus brief, the Court noted that "hundreds of thousands of children are presently being raised by such couples." discussion of harms that befall children gave rise to the Court's most overt reference to minority stress (although it did not use that term). It stated: "Without the recognition, stability, and predictability marriage offers, their children suffer the stigma of knowing their families are somehow lesser .... The marriage laws at issue here thus harm and humiliate the children of same-sex couples." 105

As noted earlier, the Brown opinion similarly focused on the harms of policies that segregated black children. ${ }^{106}$ The Obergefell Court's description of harm in this section of its analysis links marriage policy to internalized stigma ("suffer[ing] the stigma of knowing their families are somehow lesser"), which was also the focus of Brown's analysis, but largely overlooks the law's role in fostering stigma among peers, schoolteachers, extended family members, and the broader society. ${ }^{107}$ Both Brown and Obergefell raise concerns that the Court led with a description of harms imposed on innocent and vulnerable children to divert attention from adults' stake in regimes that stigmatized racial and sexual minorities. ${ }^{108}$ In Obergefell, the focus on children may have seemed safer and more neutral than engaging the social status of sexual minorities (particularly gay men who are not raising children), whom some continue to view as sexually deviant and thus morally unfit for marriage, ${ }^{109}$ or heterosexual adults who oppose same-sex marriage because of such stereotypes. Brown's emphasis on the fragile psyches of black children was similarly incomplete; it ignored the "psychological wage of whiteness" that many white adults perceived as a benefit of segregation. ${ }^{110}$ Nor did the Brown Court discuss how segregation harmed white children by instilling myths about racial difference and white supremacy that have endured long into adulthood for many white Americans. ${ }^{111}$

${ }^{104}$ Id. (citing Brief for Gary J. Gates as Amicus Curiae in Support of Petitioners at 4, Obergefell, 135 S. Ct. 2584 (Nos. 14-556, 14-562, 14-571, 14-574), 2015 WL 1021451).

${ }^{105} \mathrm{Id}$. at $2600-01$ (citation omitted).

106 See supra notes 35-36 and accompanying text.

107 Cf. Guinier, supra note 36, at 102 ("Brown's asymmetric focus on the psychological damage segregation did to blacks gave the psychological benefits segregation conferred on whites short shrift.").

108 Brown, of course, specifically concerned the rights of schoolchildren, while Obergefell primarily concerned the rights of adults.

109 See Robinson \& Frost, supra note 1 (critiquing this perspective).

110 Guinier, supra note 36 , at 108 .

111 See id. at 95-96, 102-03 ("The Court's measure of segregation's psychological costs counted its apparent effect on black children without grappling with the way segregation also shaped the personality development of whites."). 
With regard to the fourth benefit, Justice Kennedy wrote, marriage is a "keystone of our social order," and excluding gays and lesbians from a "building block of our national community" is harmful to them. ${ }^{112}$ At this point, the Court described stigmatic harm more broadly, referring to all same-sex couples, not just those who are raising children. "[B]y virtue of their exclusion" from marriage, Justice Kennedy declared, "[s]ame-sex couples are consigned to an instability many opposite-sex couples would deem intolerable in their own lives .... It demeans gays and lesbians for the State to lock them out of a central institution of the Nation's society." 13

A more fundamental critique of the Court's narrow discussion of stigma centers on the question of animus: whether states excluded same-sex couples from marriage because of group-based hostility. Brown largely elided the question of discriminatory intent or the reason why Whites forced black children into segregated schools. But Obergefell went a step further. Even as Justice Kennedy vindicated the rights of same-sex couples, he sought to disconnect exclusionary marriage laws from homophobia. Whereas his earlier Windsor opinion had accused opponents of same-sex marriage of harboring animus, ${ }^{114}$ he disavowed that claim in Obergefell. Indeed, Justice Kennedy went out of his way to proclaim that the view that marriage must be between one man and one woman "long has been held - and continues to be held-in good faith by reasonable and sincere people here and throughout the world." 15

This blanket blessing of opponents of same-sex marriage is in serious tension with the claim that exclusion from marriage demeaned and humiliated same-sex couples and their children. How precisely did millions of sincere and decent voters accidentally "impose stigma and injury of the kind prohibited by our basic charter"? ${ }^{116}$ Justice Kennedy never provides a satisfying answer to this puzzle. He could have looked to social science to find that, in fact, hostility toward gays and lesbians remains prevalent and

\footnotetext{
112 Obergefell v. Hodges, 135 S. Ct. 2584, 2601 (2015).

113 Id. at $2601-02$.

114 United States v. Windsor, 133 S. Ct. 2675, 2693 (2013) (identifying "strong evidence of [the Defense of Marriage Act] having the purpose and effect of disapproval of [same-sex married couples]"); id. at 2693-94 (concluding that the statute "demeans the couple," "undermines" their relationship privately and publicly, and "humiliates tens of thousands of children now being raised by same-sex couples").

115 Obergefell, $135 \mathrm{~S}$. Ct. at 2594 (emphasis added); see also id. at 2602 ("Many who deem samesex marriage to be wrong reach that conclusion based on decent and honorable religious or philosophical premises, and neither they nor their beliefs are disparaged here.").

116 Id. at $2602-03$.
} 
undergirds opposition to same-sex marriage. ${ }^{117}$ But at this juncture, Justice Kennedy disregarded the empirical literature. His extremely generous and erroneous construction of opponents of same-sex marriage is reminiscent of President Donald Trump's claim that good people were among those resisting the removal of Confederate statues in a violent confrontation in Charlottesville, Virginia, in August 2017.118 And Justice Kennedy's disavowal of homophobia may have consequences in the pending Masterpiece Cakeshop case, in which the Court is expected to decide whether commercial actors who invoke their religious faith are entitled to a constitutionally based exemption from state laws requiring businesses to provide services to LGBT people. ${ }^{119}$ Justice Kennedy's willingness in Obergefell to conceive of apparently all opponents of same-sex marriage as good and honorable people should make LGBT advocates nervous.

Ultimately, we conclude that minority stress surfaced in the Obergefell opinion only fleetingly and partially. And such references were undercut by Justice Kennedy's suggestion that minority stress does not arise from homophobia. Moreover, the opinion's acknowledgement of minority stress was overshadowed by the overarching conclusion of the four benefits of marriage that Justice Kennedy consulted to determine whether same-sex couples deserve access to the right to marry: the two groups are essentially the same and derive the same benefits from marriage. Although this focus on the benefits denied to same-sex couples may have been a strategic decision intended to ease public acceptance of the decision, the narrative emerging from the Obergefell decision disserves sexual minorities by downplaying ongoing health-related inequalities between gays and lesbians and heterosexuals arising from stigma, and by denying that hostility toward gays and lesbians and same-sex love and intimacy motivated the states' denial of the right to marry. The APHA's amicus brief provided a more expansive and ambitious framing of the relevant issue. Its opening line is: "Marriage equality is a civil rights issue-but it is a public health issue, too." 120 Because this concept did not make its way into the Obergefell opinion, readers of the

117 See generally Gregory M. Herek \& Kevin A. McLemore, Sexual Prejudice, 64 ANN. REV. PSYCHOL. 309 (2013) (reviewing empirical research on prejudice against sexual minorities and discussing factors that contribute to a social context that promotes individual expressions of prejudice).

118 See Philip Bump, Trump Puts a Fine Point on It: He Sides with the Alt-Right in Charlottesville, WASH. POST (Aug. 15, 2017), https://www.washingtonpost.com/news/politics/wp/2017/08/15/trumpputs-a-fine-point-on-it-he-sides-with-the-alt-right-in-charlottesville/ [https://perma.cc/HX6K-KQLF].

119 Adam Liptak, Justices to Hear Case on Religious Objections to Same-Sex Marriage, N.Y. TIMES (June 26, 2017), https://www.nytimes.com/2017/06/26/us/politics/supreme-court-wedding-cake-gaycouple-masterpiece-cakeshop.html [https://perma.cc/77GF-SBQB].

120 Brief of the American Public Health Association \& Whitman-Walker Health, supra note 95, at 2, *2. 
opinion might never learn of the well-documented health consequences of discrimination against LGBT people.

We close this Part by observing three additional ways in which Justice Kennedy discreetly narrowed the claim, which may have been motivated by a fear of disrupting the status quo. Not long after proclaiming that "reasonable" and "sincere" people of good faith oppose same-sex marriage, Justice Kennedy stated:

Were their intent to demean the revered idea and reality of marriage, the petitioners' claims would be of a different order. But that is neither their purpose nor their submission. To the contrary, it is the enduring importance of marriage that underlies the petitioners' contentions. This, they say, is their whole point. Far from seeking to devalue marriage, the petitioners seek it for themselves because of their respect-and need - for its privileges and responsibilities. And their immutable nature dictates that same-sex marriage is their only real path to this profound commitment. ${ }^{121}$

First, the majority's casual reference to gays and lesbians" "immutable" nature intervenes in a longstanding debate within and beyond sexual minority communities concerning whether sexual orientation is fixed or fluid. ${ }^{122}$ Although individual sexual minorities have diverse and competing understandings of the degree to which they chose their orientation, Justice Kennedy appears to conceive of sexual orientation as a fixed trait, meaning that there is little possibility that changing marriage laws will promote homosexuality and shift cultural norms. ${ }^{123}$ This language might also be understood as an effort to allay the fears of "decent and honorable" opponents of same-sex marriage that gays and lesbians seek to "recruit" people into their ranks. ${ }^{24}$ In short, Justice Kennedy declared, gays and lesbians are "born that way," and will remain a minuscule portion of the

121 Obergefell, $135 \mathrm{~S}$. Ct. at 2594; see also id. at 2596 ("[S]exual orientation is both a normal expression of human sexuality and immutable.").

122 See, e.g., Eve KosofSKy SEDGWICK, EPISTEMOlOGY OF THE Closet 1-2 (1990) (identifying competing conceptions of sexuality); Lisa M. Diamond, Female Bisexuality from Adolescence to Adulthood: Results from a 10-Year Longitudinal Study, 44 DEVELOPMENTAL PSYCHOL. 5, 9 (2008) (demonstrating considerable fluidity in identification among a sample of nonheterosexual women); Janet E. Halley, Sexual Orientation and the Politics of Biology: A Critique of the Argument from Immutability, 46 STAN. L. REV. 503, 506 (1994) (critiquing immutability argument and warning that it may divide LGBT community); Russell K. Robinson, Masculinity as Prison: Sexual Identity, Race, and Incarceration, 99 CALIF. L. REV. 1309, 1356-61 (2011) (examining Los Angeles County men's jail's attempt to identify an essential gay identity and prevent heterosexual and bisexual men from qualifying for the jail's "gay" unit).

${ }^{123}$ Cf. Obergefell, $135 \mathrm{~S}$. Ct. at 2607 (stating that expanding marriage to include same-sex couples "pose[s] no risk of harm to themselves or third parties").

124 If that was the intent of this language, we think Justice Kennedy should have named this fear as a harmful stereotype. 
population. ${ }^{125}$ This view is in tension with research evidence demonstrating that sexuality can be fluid and subject to change over one's lifetime. ${ }^{126}$

Second, throughout the majority opinion, Justice Kennedy also makes clear that his opinion applies only to "two people" who wish to marry, not to people who want to have a union of three or more partners recognized by the law. ${ }^{127}$ He thus shuts down the claims of dissenters that the majority ruling will lead to plural marriage. Third, in the above quote, the Court emphasizes same-sex couples" "need" to assimilate into traditional marriage rather than "demean" or transform it. ${ }^{28}$ This is another move that underscores the essential sameness of gays and lesbians, frames marriage equality as an assimilation project, and erases positive differences. These three rhetorical moves carefully confined the claim that the Court recognized and reaffirmed the status quo.

\section{IMAGining a MoRe InClusive Marriage Equality MOVEMENT}

The decidedly narrow scope of the claim that Obergefell embraced, as well as the tension between sameness studies and minority stress findings, betrays a broader debate within the LGBT community. Marriage has beenand remains - a divisive issue among LGBT people. Many people perceive the legal validation of same-sex marriage as recognizing LGBT people's core humanity and equality with heterosexuals. Others, however, view marriage, or at least the marriage equality movement, as an attempt to assimilate into mainstream society, which they consider a betrayal of "queer" values. From this vantage point, LGBT people should be focused on disrupting dominant norms, not blending into them.

Academics and activists have long debated this question, ${ }^{129}$ but a Pew survey of LGBT people illustrates the salience of this divide among ordinary Americans:

125 See Robinson, Unequal Protection, supra note 11, at 227-28 (identifying some structural advantages that gays and lesbians have over people of color in terms of their claims disturbing the status quo, including that only $1.7 \%$ of the public identifies as gay or lesbian).

126 See, e.g., Diamond, supra note 122.

127 See, e.g., Obergefell, $135 \mathrm{~S}$. Ct. at 2599 ; id. at 2608 ("In forming a marital union, two people become something greater than once they were."); $i d$. at 2607 ("[T]hese cases involve only the rights of two consenting adults whose marriages would pose no risk of harm to themselves or third parties."); $i d$. at 2621 (Roberts, C.J., dissenting) ("Although the majority randomly inserts the adjective 'two' in various places, it offers no reason at all why the two-person element of the core definition of marriage may be preserved while the man-woman element may not.").

128 See id. at 2594 (majority opinion).

129 See, e.g., Michael WARNER, The Trouble With Normal: SEX, POlitics, AND THE ETHICS OF QUEER LIFE 113 (1999); Paula L. Ettelbrick, Since When Is Marriage a Path to Liberation?, OUT/LOOK: NAT'L GAY \& LESBIAN Q., Fall 1989, at 9, reprinted in LESBIANS, GAY MEN, AND THE LAW 401-05 
About half of survey respondents (49\%) say the best way to achieve equality is to become a part of mainstream culture and institutions such as marriage, but an equal share say LGBT adults should be able to achieve equality while still maintaining their own distinct culture and way of life. ${ }^{130}$

Thus, the strategy of the LGBT movement and its allies in Obergefellwhich emphasized sameness to the detriment of acknowledging differences-is in tension with the values of half of the relevant community. ${ }^{131}$

The discomfort that a significant number of LGBT people have about marriage's prominence overlaps with racial and socioeconomic disparities. Studies suggest that middle-class and affluent people, whether heterosexual or LGBT, are more likely to take advantage of the right to marry or seek a civil union or domestic partnership. ${ }^{132}$ Low-income people of color, especially African-Americans, are potentially less likely to benefit from the efforts of the marriage equality movement as much as affluent white people in part because people of color are underrepresented in the population of LGBT people in same-sex partnerships. ${ }^{133}$ This practical disparity in access

(William B. Rubenstein ed., 1993); Katherine M. Franke, Commentary, The Domesticated Liberty of Lawrence v. Texas, 104 COLUM. L. REV. 1399, 1414 (2004).

130 PEW RESEARCH CTR., A SURVEY OF LGBT AMERICANS: ATTITUDES, EXPERIENCES AND VALUES IN CHANGING TIMES 12-13 (2013), http:/assets.pewresearch.org/wp-content/uploads/sites/3/2013/06/ SDT_LGBT-Americans_06-2013.pdf [https://perma.cc/LU92-8UKC].

${ }^{13} 1$ LGBT people differ significantly in terms of which "differences" they see as linked to LGBT identity and worthy of recognition or preservation. For example, several scholars have critiqued monogamy and argued that public sex is integral to queer identity. See, e.g., WARNER, supra note 129, at 113-14. But see Robinson \& Frost, supra note 1, at 6-7 (challenging attempts to "fuse" gay identity with promiscuity and HIV). By contrast, the differences that we call attention to primarily concern the impact of minority stress on LGBT lives and differences related to egalitarian relationship practices and raising children who are more likely to subscribe to gender and sexual orientation equality.

132 See, e.g., GARY J. GATES, DEMOGRAPHICS OF MARRIED AND UNMARRIED SAME-SEX COUPLES: ANALYSES OF THE 2013 AMERICAN COMMUNITY SURVEY 1 (2015), https:/williamsinstitute.law.ucla.edu/wp-content/uploads/Demographics-Same-Sex-Couples-ACS2013March-2015.pdf [https:/perma.cc/WG6S-YRFN] ("[P]overty is substantially less common among married same-sex couples (4\%) than among unmarried same-sex couples (18\%)."); Hui Liu et al., SameSex Cohabitors and Health: The Role of Race-Ethnicity, Gender, and Socioeconomic Status, $54 \mathrm{~J}$. HEALTH \& SOC. BEHAV. 25, 32-33 (2013) (demonstrating that same-sex cohabiting couples report higher socioeconomic status than different-sex cohabiting couples or single men and women).

133 See GATES, supra note 132 , at 2 (stating that just $23 \%$ of people in married same-sex couples are people of color, compared to $26 \%$ of those in married different-sex couples); Christopher Carpenter $\&$ Gary J. Gates, Gay and Lesbian Partnership: Evidence from California, 45 DEMOGRAPHY 573, 579 (2008) (analyzing two California surveys with large samples of gays and lesbians and concluding that "partnered gay men are older, more likely to be white, and more highly educated compared with nonpartnered gay men"); $i d$. (finding that partnered lesbians are more likely to be white than the overall category of lesbians); $i d$. at 583-85 (finding that those in legally registered domestic partnerships are more likely to be white and have the highest incomes of all gay men and that black men and women are particularly underrepresented in officially registered domestic partnerships). Blacks are underrepresented both among those in same-sex and different-sex marriages: while $13.3 \%$ of Census respondents identified 
to marriage has provoked some harsh critiques of the marriage movement. For example, Kenyon Farrow, a black queer man, wrote "Is Gay Marriage Anti Black???"134 Angela Harris, who is a black woman, has offered a formidable critique of what she calls the LGBT movement's "neoliberal" foundation. ${ }^{135}$ In a piece written before Obergefell, she worried that the Supreme Court's eventual embrace of same-sex marriage would simply create a path "from Stonewall to the suburbs" for affluent gays and lesbians, leaving many sexual minorities behind. ${ }^{136}$

Marriage equality is a deeply important step toward eliminating discriminatory social policies and structural stigma in LGBT lives, but we regret that the framing of the issue in some legal arguments and public discourse has exacerbated division. If the people who organized, funded, and litigated for marriage equality had been more aware of and committed to protecting the interests of marginalized members of the community-of "[1]ooking to the bottom"137-how would they have articulated the claim for marriage equality? This reimagined marriage equality claim would have offered more than symbolic benefits to LGBT people who face social obstacles in their pursuit of marriage or are not interested in marriage. At a minimum, it would have created a foothold for courts and other government bodies to recognize the full scope of the injuries that sexual minorities experience because of homophobia and heterosexism-not simply the formal denial of a marriage license. Instead, the questionable turns and strategic choices of the marriage equality movement narrowed the scope of the underlying claim and the class of people who stood to benefit from a victory.

For example, the marriage equality movement made the strategic decision to focus only on gays and lesbians, rather than all sexual minorities. With virtual uniformity, the movement's briefs recited "gays and lesbians"

\footnotetext{
as "Black or African-American alone," QuickFacts, U.S. CENSUS BUREAU, https://www.census.gov/ quickfacts/fact/table/US/PST045216 [https://perma.cc/T8Y6-ZCB2], 6\% of those in same-sex married couples and $7 \%$ of those in different-sex married couples identify as Black or African-American, see GATES, supra note 132 , at 4.

134 See Kenyon Farrow, Is Gay Marriage Anti Black???, CHICKEnBONES (Sept. 29, 2007), http://www.nathanielturner.com/isgaymarriageantiblack.htm [https://perma.cc/3G3L-JM9Z]; see also Marlon M. Bailey et al., Colloquy, Is Gay Marriage Racist?: A Conversation with Marlon M. Bailey, Priya Kandaswamy, and Mattie Udora Richardson, in THAT'S REVOLTING!: QUEER STRATEGIES FOR RESISTING ASSIMILATION 113, 113-14, 117-19 (Mattilda, a.k.a. Matt Bernstein Sycamore ed., 2008).

135 Angela P. Harris, From Stonewall to the Suburbs?: Toward a Political Economy of Sexuality, 14 WM. \& MARY BILL RTS. J. 1539 (2006).

136 Id. at 1582.

137 Mari J. Matsuda, Looking to the Bottom: Critical Legal Studies and Reparations, 22 HARV. C.R.C.L. L. REV. 323, 324 (1987) (arguing that "those who have experienced discrimination speak with a special voice to which we should listen").
} 
as the relevant class, even though bisexual, transgender, and other sexual or gender minorities stood to benefit from marriage equality. ${ }^{138}$ To be sure, studies suggest that gays and lesbians are far more likely to seek to marry a person of the same sex than a bisexual person. ${ }^{139}$ The vast majority of bisexuals in cohabiting relationships are partnered with someone of a different sex. ${ }^{140}$ However, this pattern is at least partly explained by the fact that a relationship with a different-sex partner offers a path to marriage and higher social status, whereas same-sex relationships are stigmatized and (before the Court's decisions in Windsor and Obergefell) were generally ineligible for marriage. ${ }^{141}$ Thus, the current partnering patterns of bisexuals should not be understood as fixed, but rather receptive to social and legal changes that make same-sex partnering a more viable option. ${ }^{142}$

Transgender people also have a more complicated relationship to marriage. Some transgender people could marry pre-Windsor and Obergefell because they could change their legal sex under state law, because they chose to marry someone of a different sex, or because the state considered their relationship to be different-sex, even though the transgender people considered themselves to be in same-sex relationships. ${ }^{143}$ With respect to the latter group, however, the only reason why the state allowed the marriage was the state's refusal to respect the person's gender identity. In lifting state marriage limitations based on gender, Obergefell freed some transgender people to marry without disrespecting their gender identity. Therefore, although restrictive marriage laws impacted bisexual and transgender people differently, these groups still had a stake in the movement.

The "gay and lesbian" framing of the legal briefs also seems strikingly out of tune with the proliferation of identities among the youngest sexual minorities. Millennial women increasingly seem likely to prefer the label

\footnotetext{
138 See Robinson \& Frost, supra note 1, at 13; Russell K. Robinson, Marriage Equality \& Postracialism, 61 UCLA L. REV. 1010, 1060 (2014) [hereinafter Robinson, Postracialism].

139 See, e.g., Gregory M. Herek et al., Demographic, Psychological, and Social Characteristics of Self-Identified Lesbian, Gay, and Bisexual Adults in a US Probability Sample, 7 SEXUALITY RES. \& SOC. POL'Y 176, 194 (2010).

140 See id.

141 To be clear, we do not mean to suggest that all bisexuals who partner with a person of a different sex are pursuing status or assimilation. The point is to be mindful of how, in general, power and status can influence relationship choices, rather than to identify any particular person as acquiescing to compulsory heterosexuality.

142 See Michael Boucai, Sexual Liberty and Same-Sex Marriage: An Argument from Bisexuality, 49 SAN DIEGO L. REV. 415, 416 (2012) (arguing that "same-sex marriage bans channel individuals, particularly bisexuals, into heterosexual relations and relationships, impermissibly burdening sexual liberty interests").

143 Julie A. Greenberg \& Marybeth Herald, You Can't Take It with You: Constitutional Consequences of Interstate Gender Identity Rulings, 80 WASH. L. REV. 819, 833-36 (2005); Robinson, Postracialism, supra note 138 , at $1061 \mathrm{n} .267$.
} 
"queer" to "lesbian," in part because it suggests a more fluid set of attractions to people of different genders. Young people are also claiming terms like "pansexual" or refusing sexual labels altogether. ${ }^{144}$ Now, we are not naïve enough to suggest that Justice Kennedy is prepared to utter (or understand) the word "pansexual." Our point is that the narrow construction of the class as "gay or lesbians" may eventually make Obergefell's conception of sexual minorities look anachronistic and may reduce its relevance to younger generations.

We see similar limitations in the scholarly literature cited in the APA brief. Marriage equality litigators chose to represent the relevant class as having a fixed, stable identity, which likely explains why they did not directly engage with identities such as "bisexual," which may be understood as affording the individual more choice. Moreover, the lawyers selected plaintiffs who were likely to appeal to the Justices in that they were disproportionately white and middle- or upper- class. ${ }^{145}$ While the lawyers who fought for marriage equality generally made strategic choices that limited the relevant class and how it was represented, social science scholars were more likely to confront practical constraints preventing them from developing a more inclusive sample, often resulting in samples that were disproportionately white, affluent, and female. ${ }^{146}$ The scholars also faced

144 See, e.g., Kristi E. Gamarel et al., Identity Safety and Relational Health in Youth Spaces: A Needs Assessment with LGBTQ Youth of Color, 11 J. LGBT YOUTH 289, 297 (2014); Lauren McInroy \& Shelley L. Craig, Articulating Identities: Language and Practice with Multiethnic Sexual Minority Youth, 25 COUNSELLING PSYCHOL. Q. 137, 145 (2012) (describing different labels used in the LGBTQ community). According to one definition, pansexual identity "is used merely to express the openness and fluidity to people of all genders." What Is Pansexual?, STOP-HOMOPHOBIA.COM, http:/www.stophomophobia.com/pansexuality.htm [https://perma.cc/5VCL-LG6Q].

${ }^{145}$ Robinson \& Frost, supra note 1, at 12-13. For example, Edith Windsor's lawyer argued that a case involving a person who filed for bankruptcy would make for an unsympathetic plaintiff. Ariel Levy, The Perfect Wife, NEW YORKER (Sept. 30, 2013), http:/www.newyorker.com/magazine/2013/09/30/theperfect-wife [https://perma.cc/7D2V-NFXH]. Of the plaintiffs in Obergefell, 83\% were white, compared to $67 \%$ of the LGBT community. While $24 \%$ of the LGBT community makes less than $\$ 24,000$ in income, none of the Obergefell plaintiffs fell into this category. Cynthia Godsoe, Perfect Plaintiffs, 125 YALE L.J. F. 136, 139 (2015).

146 See, e.g., Stephen Erich et al., A Comparative Analysis of Adoptive Family Functioning with Gay, Lesbian, and Heterosexual Parents and Their Children, 1 J. GLBT FAM. STUD. 43, 51 (2005) (stating that over $91 \%$ of gay/lesbian respondents and $88 \%$ of heterosexual respondents were Caucasian); Rachel H. Farr et al., Parenting and Child Development in Adoptive Families: Does Parental Sexual Orientation Matter?, 14 APPLIED DEVELOPMENTAL SCI. 164, 167 (2010) (reporting that 80\% of parents were white and just 3\% were "Latino, Asian, or Multiethnic/Biracial"); id. at 168, 175 (describing demographic characteristics of sample as "high educational attainment" and "high income levels" and that lesbian and gay parents "were situated within relatively supportive legal landscapes"); Charlotte J. Patterson, Family Relationships of Lesbians and Gay Men, 62 J. MARRIAGE \& FAM. 1052, 1064 (2000) ("[M]uch of the research has involved small samples that are predominantly White, well-educated, middle class, and American; the degree to which results would hold with other populations is thus difficult to evaluate."); $i d$. at 1061 (summarizing literature and concluding that "[1]ittle information is yet available on differences 
methodological challenges in identifying hard-to-find populations, such as bisexuals and transgender people. ${ }^{147}$ Nonetheless, it is valuable to contemplate how the lawyers' rhetoric and the scientific studies similarly gravitated toward the most elite members of the LGBT community instead of "looking to the bottom."

The marriage equality movement's use of social science evidence may have also strategically omitted several significant differences between samesex and different-sex relationships. ${ }^{148}$ This sameness strategy seemingly entailed glossing over things that make same-sex couples unique. The APA brief provides an illustrative example, although the discussion could be extended to characterize the marriage equality movement's use of social science more broadly. The following discussion focuses only on studies cited in the APA brief and brings to the fore themes that were overlooked by that brief. Our review shows that social science scholarship can be useful not just in supporting strategic legal arguments of no difference but also in its potential to highlight positive differences that might serve as exemplars for all families. We organize this list of apparent differences beginning with those that we think would have been the least controversial within the marriage equality movement to those that could have generated significant controversy and legal risk. ${ }^{149}$

First, several studies suggest that female couples and, to a lesser extent, male couples, divide household labor and childrearing in a more egalitarian fashion than heterosexual couples. Specifically, a second mother is more

attributable to race or ethnicity, family economic circumstances, cultural environments, or related variables").The centrality of affluent white lesbians in this body of scholarship is especially concerning because recent studies suggest that, within the LGBT community, women of color are the most likely to be parents, and men of color are more likely to parent than white men, and that families raising children are likely to face socioeconomic disadvantage. See, e.g., GATES, supra note 132, at 6-7.

147 See, e.g., Herek et al., supra note 139 , at 178, 182.

148 Our discussion builds on prior critiques by two sociologists and a subsequent article by a law professor. See Judith Stacey \& Timothy J. Biblarz, (How) Does the Sexual Orientation of Parents Matter?, 66 AM. SOC. REV. 159 (2001); Clifford J. Rosky, Like Father, Like Son: Homosexuality, Parenthood, and the Gender of Homophobia, 20 YALE J.L. \& FEMINISM 257 (2009).

149 We note briefly two differences that we have discussed elsewhere, which suggest a divergence between gay men and lesbians, and which posed significant risks of threatening the marriage equality claim. Some studies, based primarily on nonprobability samples, suggest that gay men in relationships are less likely than lesbians to endorse and practice monogamy. See Russell K. Robinson, Diverging Identities, in AFTER MARRIAGE EquALiTy: THE Future OF LGBT Rights 212 (Carlos A. Ball ed., 2016) [hereinafter Robinson, Diverging Identities] (discussing studies). A related issue is HIV prevalence, which is much higher among gay men than lesbians. See Robinson \& Frost, supra note 1, at 8 n.22, 18. While discussing HIV's impact on gay male relationships might have generated sympathy, it also might have triggered fears of gay male promiscuity. See id. at 22 (describing pervasive stereotypes that "gay and bisexual men are incapable of maintaining enduring, healthy relationships because they are less sexually responsible, more sex-focused, and indiscriminate in selecting sex partners, as compared to straight people; because of their sexuality, [they] are inherent vectors of disease"). 
likely than a father to be engaged in childrearing. ${ }^{150}$ Second, same-sex parents may be less likely to use physical punishment. ${ }^{151}$ As virtually all of these studies emphasize, children of same-sex parents are as likely as children of heterosexual parents to achieve positive outcomes. It is noteworthy, however, that same-sex partners appear to do this while using less physical punishment.

Third, some studies have found that children of female same-sex parents actually surpassed children of different-sex parents on certain measures of healthy development. For example, some studies found that adolescents raised by two mothers "scored significantly higher on ... selfesteem than the adolescents in mother-father families" and "scored significantly lower on the conduct problems scale."152 A review by E.C. Perrin declares: "growing up with parents who are lesbian or gay may confer some advantages to children. They have been described as more tolerant of diversity and more nurturing toward younger children than children whose parents are heterosexual.",153

Fourth, some scholarship suggests that children of same-sex parents are more likely to endorse gender equality. ${ }^{154}$ A related question is whether parents should pressure their children to adhere to rigid gender roles. ${ }^{155} \mathrm{We}$ suspect that there is consensus among liberals that the former outcome (greater endorsement of gender equality) is positive, but liberals might differ on the value of the latter outcome (more gender flexibility). For instance, one study found that "daughters of lesbian mothers were more likely to be

${ }^{150}$ See, e.g., Henny Bos et a1., Lesbian \& Heterosexual Two-Parent Families: Adolescent-Parent Relationship Quality and Adolescent Well-Being, 24 J. CHILD \& FAM. STUD. 1031, 1032 (2014) ("Studies have shown that co-mothers in intact planned lesbian families were more involved in childrearing than fathers in intact mother-father families."); Patterson, supra note 146, at 1054; Charlotte J. Patterson, Lesbian and Gay Parents and Their Children: A Social Science Perspective, in CONTEMPORARY PERSPECTIVES ON LESBIAN, GAY, AND BISEXUAL IDENTITIES 141, 147, 152 (D.A. Hope ed., 2009) (reporting that lesbian mothers exhibited more equitable division of labor and were more satisfied with division, which may be better for kids); Charlotte J. Patterson et al., Socialization in the Context of Family Diversity, in HANDBOOK OF SOCIALIZATION 202, 217 (J.E. Grusec \& P.D. Hastings eds., 2d ed. 2015) ("[L]esbian couples report sharing household tasks and parenting duties more equally than do heterosexual couples.").

151 Patterson et al., supra note 150, at 214 ("Lesbian mothers were . . less likely to report "smacking." ); id. at 217 ("Lesbian mothers and gay fathers are less likely than heterosexual parents to report the use of physical punishment.").

152 Bos et al., supra note 150, at 1039.

153 E.C. Perrin et al., Technical Report: Coparent or Second-Parent Adoption by Same-Sex Parents, 109 PEDIATRICS 341, 343 (2002).

154 See, e.g., Henny Bos \& Theo G.M. Sandfort, Children's Gender Identity in Lesbian and Heterosexual Two-Parent Families, 62 SEX ROLES 114, 119 (2010) (finding that children in lesbian families "were less likely to regard their own gender as superior").

155 See id. (stating that children in lesbian families "reported less parental pressure to conform to gender stereotypes than children in heterosexual two-parent families") 
described as taking part in rough and tumble play or as playing with 'masculine' toys such as trucks and guns." 156 People who promote traditional gender roles might see in these findings evidence of gay and lesbian parents problematically promoting gender nonconformity. ${ }^{157}$

Finally and perhaps most controversially, some studies indicate that children of same-sex parents are more open than children of different-sex parents to romantic or sexual relationships with a person of the same sex. ${ }^{158}$ A study by Henny Bos and Theo Sandfort found that children with two mothers "[were] more likely to question future heterosexual romantic involvement." 159 While legal arguments for marriage equality may have benefitted from avoiding this finding, an alternative take on these findings reveals something inspiring. Most LGBT people were raised in settings in which heterosexual parents, peers, and institutions such as schools and churches communicated in explicit or implicit ways that they should be heterosexual and cisgender. ${ }^{160}$ As a result, much of the internal work that sexual and gender minorities must do as they approach emerging adulthood

156 Patterson, supra note 146 , at 1059

157 The ASA brief seems to respond to these fears by claiming that "among same-sex parents, one partner commonly fills the 'male-instrumental role while the other fills the female-expressive role' in rearing their children." Brief of the American Sociological Association, supra note 93, at 19 (quoting DAvid Popenoe, Life Without Father: COMPELling New EVIDENCE That FatherhoOd AND MARRIAGE ARE INDISPENSABLE FOR THE GOOD OF CHILDREN AND SOCIETY 147 (1996)). This passage is sadly reminiscent of the essentialist question that heterosexuals sometimes ask of same-sex couples: "Who's the man, and who's the woman?" While sexual minorities should be free to understand their relationship in gender-complementary terms, the ASA's thinly supported claim that this is a "common" configuration appears to cater to a heteronormative assumption that same-sex couples can only be understood as a variation on a heterosexual relationship.

158 See Charlotte J. Patterson, Children of Lesbian and Gay Parents: Psychology, Law, and Policy, 64 AM. PSYCHOLOGIST 727, 733 (2009) ("[T] he young adult offspring of lesbian mothers report feeling fewer antigay sentiments than do the offspring of heterosexual mothers. . ." (citing FIONA L. TASKER \& SUSAN GOLOMBOK, GROWING UP IN A LESBIAN FAMILY: EFFECTS ON CHILD DEVELOPMENT (1997))). Curiously, Patterson characterized this and other findings of difference as "not relevant to policy debates." $I d$. As we indicate in the text, we think such positive differences are deeply relevant.

159 Bos \& Sandfort, supra note 154, at 120; see also Patterson, supra note 146, at 1056 (discussing a study by Marjorie Hill that found that African-American lesbian mothers were "more relaxed about sex play"); Patterson et al., supra note 150, at 216 (noting study that found that young adults with lesbian mothers were more likely than those raised by heterosexual parents to acknowledge attraction to the same sex and act on it, but not more likely to identify as lesbian or gay (citing TASKER \& GOLOMBOK, supra note 158)).

${ }^{160}$ See Kathleen P. Farrell, HIV on TV: Conversations with Young Gay Men, 9 SEXUALITIES 193, 194 (2006) (noting how young gay men learned about HIV stigma from media sources); David E. Newton, Representations of Homosexuality in Health Science Textbooks, 4 J. HOMOSEXUALITY 247, 248-49, 251 (1979) (reviewing textbooks and finding that very few mentioned homosexuality, and those that did depicted homosexuality in a negative light); Emily Sweetnam Pingel et al., Creating Comprehensive, Youth Centered, Culturally Appropriate Sex Education: What Do Young Gay, Bisexual, and Questioning Men Want?, 10 SEXUALITY RES. \& SOC. POL'Y 293, 297-98 (2013) (reporting that gay-identified children were more likely to seek guidance online as opposed to asking their parents or people at school). 
entails figuring out how to reconcile their feelings, attractions, and evolving sense of personal identity with parental and social expectations.

This dilemma is the source of much minority stress, and parental expectations in particular may keep some people from ever coming out of the closet. ${ }^{61}$ From this vantage point, children of gays and lesbians enjoy greater freedom to question their sexual identities without fear of parental rejection - a benefit that we should seek to extend to all children. In addition, the findings on gay and lesbian parents' greater acceptance of gender flexibility might suggest that they would be more supportive if a child eventually identified as transgender. ${ }^{162}$

Most of these findings were downplayed not only by the APA but by many of the scholars who produced these studies. The Bos and Sandfort study, discussed previously, is exceptional in its candor: "In sum, our findings regarding feeling parental pressure to conform to gender stereotypes, feeling that their gender is superior, and doubting future heterosexual romantic involvement, our findings do not support the "no difference' consensus in empirical research on lesbian-parent families...."163 The marriage equality movement's omission of the differences that we have summarized provided an incomplete and misleading description of the relevant research. A more frank and transparent exploration of similarities and differences might have helped bridge fissures in the LGBT community regarding whether marriage equality is about assimilation and denial of differences.

The strategic reasons for avoiding some of these findings are obvious, particularly the findings concerning gender flexibility and openness to a same-sex relationship. But others seem much less risky, such as findings that lesbian mothers are more engaged and egalitarian parents. These studies offered a chance to vindicate the interests of same-sex parents and their children and call into question certain aspects of heteronormativity. Therefore, we do not think that strategic concerns fully justified the marriage equality movement's unyielding adherence to the "no significant

161 Deborah Tharinger \& Greg Wells, An Attachment Perspective on the Developmental Challenges of Gay and Lesbian Adolescents: The Need for Continuity of Caregiving from Family and Schools, 29 SCH. PSYCHOL. REV. 158, 158 (2000); Gill Valentine et al., Coming Out and Outcomes: Negotiating Lesbian and Gay Identities with, and in, the Family, 21 ENV'T \& PLAN. D: SOC'Y \& SPACE 479, 483-84 (2003)

162 Our discussion is somewhat speculative because the APA did not cite any studies concerning parents of children who identify as transgender. Moreover, we recognize that among lesbian, gay, and bisexual (LGB) people, there are different, and sometimes competing, conceptions of gender. And there is considerable transphobia among some LGB people. This question of whether LGB parents are more supportive of transgender children strikes us as an important future scholarly inquiry.

163 Bos \& Sandfort, supra note 154, at 124 (citations omitted). 
differences" mantra. Moreover, our review is a reminder of how oppressive forces infuse and structure legal arguments that are intended to overturn those very same forces. ${ }^{164}$ A movement to upend homophobic marriage laws was itself confined by homophobia, which influenced which arguments could be articulated.

The Court's opinion in Obergefell focused narrowly on marriage and offered too little to sexual minorities who are not partnered or raising children. The Court's marriage opinions have refrained from declaring sexual orientation a "suspect" or "quasi-suspect" class, a holding that would have had major implications for every claim based on sexual orientation, reaching beyond Obergefell's focus on marriage and parenting. Moreover, the marriage opinions could be read to suggest that achieving marriage is the pinnacle of LGBT rights.

The marriage equality movement bears some responsibility for this framing because its use of social science largely framed denial of access to marriage as a unique harm rather than sufficiently connecting it to overlapping structural forms of subordination, which cannot be eradicated simply by granting marriage licenses. The movement's narrow focus seems most beneficial for the most affluent members of the class, those who managed to obtain stable, satisfying, and exemplary relationships and, in some cases, to raise healthy children, despite significant exposure to minority stress. The plaintiffs and others who are similarly situated accomplished these positive outcomes without significant government assistance. We regret the failure of the marriage equality movement also to attend to those who have been less fortunate and are in need of greater governmental aid. This framing reinforced critiques of LGBT rights as "neoliberal" in character. ${ }^{165}$

Many sexual minorities are not prepared to take advantage of marriage equality because they are struggling with basic needs, such as access to stable housing, or because they are incarcerated. LGBT people are disproportionately likely to be homeless and to be incarcerated. ${ }^{166}$ Even in

164 Judith Stacey and Timothy Biblarz have made a similar point concerning the framing and reporting of social science studies that are relevant to policy debates. See Stacey \& Biblarz, supra note 148 , at 160 (" $[\mathrm{T}]$ he pervasiveness of social prejudice and institutionalized discrimination against lesbians and gay men [] exerts a powerful policing effect on the basic terms of psychological research and public discourse on the significance of parental sexual orientation.").

165 See Harris, supra note 135, at 1581-82.

166 Laura E. Durso \& Gary J. Gates, Serving Our Youth: Findings from a National Survey of SERvices Providers Working With Lesbian, Gay, BiseXual, and TRANSGENDER YOUTH WHO ARE HOMELESS OR AT RISK OF BECOMING HOMELESS 3 (2012), https:/williamsinstitute.law.ucla.edu/wp-content/uploads/Durso-Gates-LGBT-Homeless-YouthSurvey-July-2012.pdf [https:/perma.cc/DE2Z-4X9W] ("LGBT youth represent between 30\% and 43\% of those served by drop-in centers, street outreach programs, and housing programs ...."); Bianca D.M. 
the marriage equality era, LGBT sexuality remains highly stigmatized. As a result, many sexual minorities continue to hide their identities and to conduct any sexual or romantic relationships in secret. Many sexual minorities' attempts to form enduring romantic relationships are hindered by discrimination at work, at school, in public, and from parents and other family members. ${ }^{167}$

As important as the couple-focused social science work is, it does not represent sexual minorities who are not in such relationships but may desire them. The minority-stress-related barriers and challenges that sexual minorities face in the process of identifying potential partners, dating, and negotiating intimacy are equally deserving of scientific examination. People currently in long-term committed relationships appear to be about one-half of the community of people who identify as LGBT. ${ }^{168}$ Moreover, identity appears to influence access to relationships. For example, studies suggest that women are more likely to be in committed relationships. According to a 2013 Pew study, $60 \%$ of gay men are single and $40 \%$ are in a committed relationship. By contrast, 34\% of lesbians are single and $66 \%$ are in a relationship. ${ }^{169}$ Several other studies have also found that gay men are less likely than lesbians to be partnered. ${ }^{170}$ In the more inclusive marriage equality claim that we imagine, the lawyers would have used the social science to shed light on challenges that apply throughout the LGBT community, including at various stages of relationship formation and dissolution.

Wilson et al., Disproportionality and Disparities Among Sexual Minority Youth in Custody, 79 J. YouTH ADOLESCENCE 1547,1553 (2017) (finding that nearly $40 \%$ of girls in custody identify as lesbian, gay or bisexual); Lara Stemple \& Ilan H. Meyer, The Unspoken Horror of Incarcerated LGBT People, ADVOCATE (Feb. 23, 2017, 5:06AM), https://www.advocate.com/commentary/2017/2/23/unspokenhorror-incarcerated-lgbt-people [https://perma.cc/J7JW-JTPQ] ("The incarceration rate of lesbian, gay, and bisexual people is three times greater than that of American adults generally.").

167 See generally, e.g., David M. Frost et al., Couple-Level Minority Stress: An Examination of SameSex Couples' Unique Experiences, 58 J. HEALTH \& SOC. BEHAVIOR 455, 456 (2017) (discussing unique types of discrimination faced by people in same-sex relationships).

168 PEW RESEARCH CTR., supra note 130, at 70 (finding that 54\% of LGB people are in relationships of any duration). This number, however, includes many bisexuals who are in relationships with someone of a different sex ( $40 \%$ of the total LGB people in relationships); just $9 \%$ of bisexuals in relationships have a same-sex partner. $I d$. at 5,82 .

169 Id. at 70.

${ }^{170}$ See, e.g., Carpenter \& Gates, supra note 133, at 587 ("We find partnership estimates of about $37 \%$ to $46 \%$ for gay men and $51 \%$ to $62 \%$ for lesbians."); $i d$. (summarizing related studies); Herek et al., supra note 139 , at 194 (noting that " $60 \%$ of gay men and $57 \%$ of bisexual men were not in a committed relationship, compared with fewer than one fourth of lesbians and bisexual women."); see also Robinson, Diverging Identities, supra note 149, at 214-15 (discussing additional studies). 


\section{CONCLUSION}

This Essay highlights how various institutional pressures influence and, in some cases, confine civil rights claims and the presentation of social science research that bears on such claims. We have shown the importance of holistic, multidimensional representations of stigmatized groups rather than, for example, framing sexual minorities as only the same as or only different than heterosexuals. Marriage equality advocates treated all differences as problematic, yet we recognize that some differences arise from discrimination-which ought not be minimized — and other differences may be positive. The centrality of the most privileged gays and lesbians in the marriage equality movement obscured how minority stress, race, class, gender identity, and other factors overlap to limit access to relationships and marriage, even after Obergefell. Thus, marriage equality lawyers' attempt to "play it safe" may have exposed LGBT people to future vulnerabilities by downplaying the effects of homophobia.

Although the first third of this Essay focused on race and the remainder concerns sexual orientation, we have sought to show how race and sexuality are intertwined and should not be understood as distinct struggles. ${ }^{171}$ For example, there is evidence that being a sexual or gender minority (such as a black transgender woman) compounds the discrimination generally faced by black and brown people in the criminal justice system. ${ }^{72}$ Thus, our story about judicial indifference to racial disparities in criminal law should not be understood as a story disconnected from sexual orientation and gender identity. Similarly, our sketch of a more inclusive marriage equality movement makes evident how the most marginalized sexual and gender minorities, including people of color, were relegated to the sidelines in Obergefell. This dynamic unnecessarily perpetuated perceptions that marriage equality is a white, assimilationist project. We have also sought to draw doctrinal connections between cases that otherwise might be regarded as strange bedfellows, including McCleskey, Obergefell, and Grutter. The connecting thread in these cases is the judicial struggle to enforce equal protection while minimally disrupting the status quo and extricating the

\footnotetext{
171 See generally Kimberlé Crenshaw, Demarginalizing the Intersection of Race and Sex: A Black Feminist Critique of Antidiscrimination Doctrine, Feminist Theory and Antiracist Politics, 1989 U. CHI. LEGAL F. 139 (describing the tendency to view discrimination based on race and gender through a "singleaxis framework" and advocating for a broader framework of antidiscrimination research); David M. Frost, The Benefits and Challenges of Health Disparities and Social Stress Frameworks for Research on Sexual and Gender Minority Health, 73 J. SOC. IssuES 462, 467-68 (2017) (highlighting the importance of engaging with intersectionality and minority stress in research on health inequalities faced by sexual and gender minority populations).

172 See, e.g., Wilson et al., supra note 166, at 1553 (finding that sexual minority girls of color are vastly overrepresented in juvenile custody).
} 
courts from extended structural reform. Although many lawyers have catered to this judicial instinct, we want to highlight those who have pressed the Court to think bigger, including the brief by experimental psychologists in Fisher, who sought to show a connection between standardized tests and stereotype threat, and the APHA brief in Obergefell, which characterized marriage equality as a public health issue. ${ }^{173}$ We encourage scholars and lawyers similarly to resist the "fear of too much justice."

173 Although neither of these briefs was successful in infiltrating the Court's opinion, it is important to note that they did not prevent the Court from ruling for affirmative action in Fisher and marriage equality in Obergefell. This is a powerful challenge to those who argue that anything other than the narrowest and most risk-averse argument will harm the cause. 
NORTHWESTER N UNIVER S T Y LA W REVIEW 